
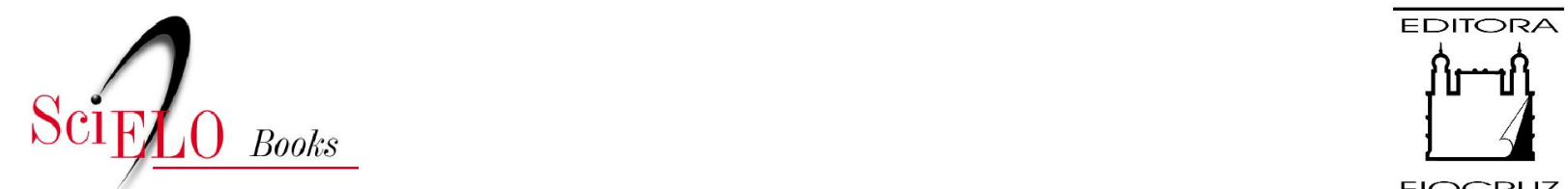

FIOCRUZ

\title{
3 - O Programa de Interiorização do Trabalho em Saúde (Pits)
}

\author{
Romulo Maciel Filho \\ Maria Alice Fernandes Branco
}

\section{SciELO Books / SciELO Livros / SciELO Libros}

MACIEL FILHO, R., and BRANCO, M. A. F. O Programa de Interiorização do Trabalho em Saúde (Pits). In: Rumo ao interior: médicos, saúde da família e mercado de trabalho [online]. Rio de Janeiro: Editora Fiocruz, 2008, pp. 83-157. ISBN: 978-85-7541-601-3. Available from: doi: $\underline{10.7476 / 9788575416013.005}$. Also available in ePUB from: http://books.scielo.org/id/64g49/epub/maciel-9788575416013.epub.

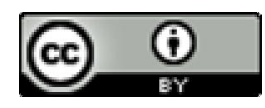

All the contents of this work, except where otherwise noted, is licensed under a Creative Commons Attribution $\underline{4.0 \text { International license. }}$

Todo o conteúdo deste trabalho, exceto quando houver ressalva, é publicado sob a licença Creative Commons Atribição 4.0.

Todo el contenido de esta obra, excepto donde se indique lo contrario, está bajo licencia de la licencia Creative Commons Reconocimento 4.0. 


\section{O Programa de Interiorização do Trabalho em Saúde (Pits)}

A análise do Programa de Interiorização do Trabalho em Saúde (Pits) como estratégia para o enfrentamento da má distribuição de médicos em nosso país foi objeto de estudo da Rede Observatório de Recursos Humanos em Saúde, na Estação de Trabal ho do Centro de Pesquisa Aggeu Magalhães da Fundação Oswaldo Cruz (CPqAM/Fiocruz) (Maciel Filho, 2007).

O estudo foi realizado no período de julho de 2004 a dezembro de 2005 e consistiu de pesquisa documental e análise de dados primários e secundários. A primeira fase constou de pesquisa sobre o processo de formulação, implementação e implantação do Pits. Foram consultados documentos oficiais, legislação, relatórios, publicações técnicas e científicas e jornais de grande circulação. 0 objetivo foi obter dados e informações sobre as ações e intervenções do M inistério da Saúde, bem como sobre o contexto político e institucional que envolveu o Pits e a inserção dos demais atores.

A segunda fase foi dedicada ao estudo da implantação do Pits. Foram analisados os dados secundários dos bancos de dados gerenciais do Programa, produzidos no período de 2000 a 2004. Os dados disponíveis nesses bancos, cujo acesso foi autorizado pelo Ministério da Saúde, permitiram levantar:

- os municípios contemplados;

- o perfil demográfico, profissional e de formação dos médicos inscritos e dos selecionados;

- a origem geográfica dos médicos inscritos e dos selecionados e suas respectivas escolhas de lotação nos municípios do Programa;

- a composição das equipes de saúde interiorizadas;

- a permanência, desistência, abandono ou desligamento de médicos e seu respectivo perfil. 
Nessa fase, o estudo também levantou dados primários junto aos médicos que se inscreveram e/ ou atuaram no Pits e junto a formuladores e gestores do Programa. No caso dos médicos, a obtenção dos dados se deu por meio de um questionário, formulado especificamente para este fim. O questionário foi construído em duas versões, ambas compostas por perguntas de múltipla escolha e sem variáveis de identificação pessoal. A primeira versão, com dez questões, destinava-se aos médicos que estavam em uma das seguintes situações: ainda atuando no Pits; já tendo concluído sua participação; desistido após já estar atuando no Programa; desligado pela coordenação nacional. A segunda versão destinava-se aos profissionais que haviam desistido durante o processo seletivo ou antes de se deslocarem para o município onde iriam atuar. Nesse caso, o número total de perguntas reduzia-se para sete. As cinco primeiras perguntas foram comuns para os dois grupos.

O envio do questionário se deu por correio eletrônico com a cooperação do Ministério da Saúde, que, em julho de 2004, remeteu, através da própria coordenação do Pits, uma mensagem eletrônica aos profissionais cujos endereços constavam do banco de dados do Programa. A mensagem, além de solicitar a colaboração dos profissionais para 0 preenchimento do questionário - em link disponível na própria mensagem - , ainda continha informações a respeito da realização do estudo. 0 fato de a mensagem ter sido enviada pela coordenação do Pits e sob forma de questionário permitiu que se preservasse a privacidade e o sigilo de identificação dos profissionais. Desse modo, não houve acesso ao endereço eletrônico dos médicos, nem no envio, nem no recebimento do questionário. Ao finalizar o preenchimento, bastava ao profissional clicar na opção 'enviar', fazendo com que as respostas fossem automaticamente lançadas em um banco de dados de acesso exclusivo da equipe de pesquisa.

Responderam ao questionário 275 médicos. Cerca de metade dos respondentes era de profissionais que desistiram durante o processo seletivo, e a outra metade se dividiu entre os que desistiram antes de ir para os municípios (22,9\%), os que concluíram sua participação (10,9\%), os que desistiram após já estarem atuando no Programa ( $9,5 \%)$, os que ainda atuavam (4,4\%) e os que foram desligados (4\%).

A distribuição desses profissionais por ano de inscrição, faixa etária, região e Unidade da Federação (UF) de naturalidade e região e UF de atuação no Pits também apresentou boa representatividade. 
Para o levantamento de dados primários junto a formuladores e gestores do Pits foram escolhidos atores que, quando da formulação do Programa, representavam a então Secretaria de Políticas de Saúde (SPS), o Conselho Nacional de Secretários de Saúde (Conass) e o Conselho Nacional de Secretários M unicipais de Saúde (Conasems), além dos atores que, com a extinção da SPS, passaram a responder pela nova Secretaria de Gestão do Trabalho e da Educação na Saúde (SGTES). Foram realizadas entrevistas semi-estruturadas, com o objetivo de identificar aspectos políticos e operacionais envolvidos na formulação e implantação do Programa. Os depoimentos foram gravados em áudio, com conhecimento e autorização dos entrevistados, aos quais foram fornecidas informações prévias sobre o estudo.

O roteiro adotado foi do tipo 'focalizado', que, como explicam Souza et al. (2005) , é composto por uma lista de questões que, a princípio, serão submetidas a todos os entrevistados, mas que permite ao entrevistador ou ao entrevistado explorar mais determinada temática, relato de experiência ou ponto de vista. O roteiro assim construído possibilita que o pesquisador conduza a entrevista, estando aberto a novas descobertas, e, ao mesmo tempo, não perca o foco nas questões previamente definidas como de especial interesse para o estudo.

Além dos questionários e das entrevistas, outra fonte primária utilizada para obter dados, tanto sobre a perspectiva dos médicos quanto dos formuladores e gestores do Programa, foi o fórum virtual criado pela coordenação nacional do Pits para comunicação com e entre esses atores. Hospedado na página el etrônica do Departamento de Informática do Sistema Único de Saúde (Datasus), o conteúdo do fórum foi aqui utilizado com autorização do Ministério da Saúde. Do acervo disponível, composto por 352 mensagens, cobrindo o período de 28 de outubro de 2003 a 1 de abril de 2005, foram utilizados trechos das mensagens, sem identificação de seus autores.

A etapa seguinte consistiu da análise dos dados primários e secundários. Esse conjunto de dados foi examinado, categorizado e classificado, recombinando evidências quantitativas e qualitativas.

A análise procurou identificar os fatores e evidências envolvidos no 'como' e no 'por que' médicos e gestores participaram de uma iniciativa destinada a minimizar a má distribuição de médicos no país tendo a interiorização como estratégia. 


\section{Os Municípios Contemplados}

Ao longo da implantação do Pits, houve permanentes mudanças na lista de municípios participantes, tanto por desistência de alguns prefeitos quanto por desligamentos efetuados pela coordenação nacional em função do não cumprimento da contrapartida municipal. Tomandose como recorte a situação do banco de dados do Pits em novembro de 2002, quando essas mudanças já estavam fechadas para o ano de 2001, mais estáveis para 2002 e com definição dos municípios a serem incluídos em 2003, observa-se que, considerando os três anos, o Programa cobriu 272 municípios, localizados nas regiões Norte, Nordeste, Centro-Oeste e Sudeste (norte do estado de Minas Gerais).

A maioria dos municípios era das regiões Nordeste $(46,32 \%)$ e Norte $(45,22 \%)$. Os estados do Maranhão e Pará foram os que tiveram 0 maior número de municípios contemplados pelo Programa, com, respectivamente, $15,81 \%$ e $13,24 \%$ do total de cidades participantes.

0 perfil desses municípios foi dado pelas próprias características demográficas, epidemiológicas e da rede de serviços de saúde, já mencionadas no capítulo anterior, que os tornaram elegíveis para participar do Programa.

Dentre os 272 municípios participantes do Pits, o menos populoso, segundo dados do Censo Demográfico de 2000, possuía 1.422 habitantes, e o de maior população apresentava 38.043 habitantes. A maioria dos municípios tinha mais de 10 a 20 mil habitantes (cerca de 41\%), vindo logo em seguida a faixa de mais de 5 a 10 mil, com 30,9\%.

Eram municípios com baixa densidade demográfica. Em mais da metade deles (51,5\%) havia, no máximo, 10 hab./ $\mathrm{km}^{2}$, estando incluídos nesse percentual cerca de $14 \%$ de municípios com menos de um habitante por quilômetro quadrado. A maior densidade demográfica não ultrapassava os $145 \mathrm{hab} . / \mathrm{km}^{2}$.

Quando do início do Pits, o rendimento nominal médio da população com dez anos ou mais de idade, nos municípios contemplados, era de no máximo cinco salários-mínimos. Apenas $6,6 \%$ dos municípios enquadravam-se nessa faixa máxima de rendimento, estando a maioria $(66,5 \%)$ na faixa de um a dois salários-mínimos. 0 baixo rendimento aliava-se à baixa escolarização: em cerca de $77 \%$ dos municípios mais de $30 \%$ da população com cinco anos ou mais de idade era analfabeta, em 2000. Esse percentual chegava a atingir $65 \%$ de analfabetos em quase $11 \%$ dos municípios do Pits. 
A infra-estrutura urbana de serviços também era precária. Cerca de $48 \%$ dos municípios integrantes do Pits ainda não contavam, no ano de 2000, com energia elétrica. Esse mesmo percentual se repete no que se refere à inexistência de rede telefônica fixa. A quase totalidade deles $(87,9 \%)$ não possuía agências bancárias e aproximadamente a metade (49,6\%) não tinha agência dos Correios.

Essas e outras características, inclusive aquelas que tornaram esses municípios elegíveis para participar do Programa, estavam à disposição dos profissionais na página eletrônica em que foram feitas as inscrições. Assim, os profissionais tinham clareza sobre as precárias condições gerais de habitabilidade dessas cidades.

\section{Os Médicos no Pits}

Os processos seletivos realizados pelo Pits, ao longo dos anos de 2001, 2002 e 2003, totalizaram 4.666 inscrições de médicos, já excluídos os que não compareceram à etapa de entrevista do processo seletivo ou não efetivaram a comprovação curricular (Tabela 1).

Quase metade desses profissionais se inscreveu no processo seletivo de 2001. A cada ano foi diminuindo o número de médicos que se interessaram em participar do Programa. Se no primeiro ano o Pits conseguiu despertar o interesse de 2.284 médicos, em 2002 esse número caiu para 1.716 e em 2003 foi de apenas 666, revelando que o Programa foi se tornando cada vez menos atrativo para os médicos. Foram vários os fatores que determinaram essa perda de interesse, os quais serão explorados e analisados ao longo deste capítulo.

Tabela 1 - Distribuição dos médicos inscritos no Pits, por ano

\begin{tabular}{lrr}
\hline Ano & \multicolumn{2}{c}{ Médicos } \\
\hline & $n^{\circ}$ & $\%$ \\
\hline 2001 & 2.284 & 48,9 \\
\hline 2002 & 1.716 & 36,8 \\
\hline 2003 & 666 & 14,3 \\
\hline Total & 4.666 & 100,0
\end{tabular}

Fonte: Maciel Filho, 2007. 
Quando indagados, no questionário aplicado pelo estudo da Rede Observatório de Recursos Humanos em Saúde sobre o que os atraiu para se inscreverem no Programa, os médicos destacaram o curso de especialização (18,8\%), a remuneração oferecida $(17,6 \%)$, o fato de se tratar de um Programa do Ministério da Saúde (16,6\%) e de funcionar nos mesmos moldes do PSF (16,1\%), além da possibilidade de conhecer outras áreas do país (15,8\%) (Tabela 2). No entanto, quando se comparam os grupos de profissionais de acordo com sua situação no Programa, observa-se que aqueles que desistiram antes de atuar consideraram a remuneração como o fator mais atrativo, ao contrário dos que concluíram sua participação ou desistiram depois, para os quais o curso de especialização foi mais determinante no seu interesse em participar. No caso dos que foram desligados, o curso de especialização ficou empatado como fator mais relevante com dois outros fatores: o fato de ser um Programa do Ministério e a possibilidade de conhecer outras áreas do país.

Em nenhum dos três anos, o Pits conseguiu preencher o número inicial de 300 vagas para médicos, mesmo tendo sido chamados todos os que obtiveram qualquer ordem de classificação no Programa (Tabela 3). Essa chamada se deveu aos elevados percentuais de desistência dos profissionais antes de irem para os municípios de lotação (91,7\% em $2001,88,6 \%$ em 2002 e 87,2\% em 2003).

Ao serem indagados sobre o que os levou a desistir (Tabela 4), esses médicos apresentaram como principais fatores o surgimento de outra oportunidade profissional ( $32,9 \%$ ) e motivos pessoais ou familiares $(30,8 \%)$. Mas é expressivo - quase $15 \%$ do total - o percentual dos que atribuíram sua desistência a falhas na organização do Programa, levando ao descrédito'.

Em virtude dessas desistências, a já referida Tabela 3 mostra que os percentuais de lotação foram muito baixos em relação ao número de inscrições validadas (8,3\% em 2001, 11,4\% em 2002 e 12,8\% em 2003). Dos 4.666 médicos que se inscreveram, ao longo dos três anos de atividade do Programa, foram lotados nos municípios somente 469. Foi em 2002 que o Pits conseguiu lotar o maior número de médicos (195). Em 2001, esse número foi de 189 e, em 2003, de apenas 85 profissionais. 
Tabela 2 - Distribuição dos médicos que responderam ao questionário segundo os fatores que os atraíram para se inscreverem no Pits por situação no Programa

\begin{tabular}{|c|c|c|c|c|c|c|c|c|c|c|}
\hline \multirow{3}{*}{ Fatores de atração* } & \multicolumn{10}{|c|}{ Situação no Pits } \\
\hline & \multicolumn{2}{|c|}{$\begin{array}{r}\text { Desistiram } \\
\text { antes de } \\
\text { atuar** }\end{array}$} & \multicolumn{2}{|c|}{$\begin{array}{r}\text { Atuam } \\
\text { ou concluíram } \\
\text { sua participação }\end{array}$} & \multicolumn{2}{|c|}{$\begin{array}{r}\text { Desistiram } \\
\text { depois de } \\
\text { estar atuando }\end{array}$} & \multicolumn{2}{|c|}{ Desligados } & \multicolumn{2}{|c|}{ Total } \\
\hline & $n^{0}$ & $\%$ & $n^{0}$ & $\%$ & $n^{0}$ & $\%$ & $\mathrm{n}^{\circ}$ & $\%$ & $n^{0}$ & $\%$ \\
\hline $\begin{array}{l}\text { A necessidade de } \\
\text { emprego (estava } \\
\text { desempregado) }\end{array}$ & 32 & 6,3 & 8 & 6,1 & 0 & 0,0 & 1 & 3,7 & 41 & 5,5 \\
\hline A remuneração & 94 & 18,6 & 20 & 15,3 & 15 & 18,5 & 3 & 11,1 & 132 & 17,6 \\
\hline $\begin{array}{l}\text { O curso de } \\
\text { especial ização }\end{array}$ & 85 & 16,7 & 29 & 22,1 & 21 & 26,0 & 6 & 22,2 & 141 & 18,8 \\
\hline A tutoria & 20 & 3,9 & 5 & 3,8 & 1 & 1,2 & 0 & 0,0 & 26 & 3,5 \\
\hline $\begin{array}{l}\text { A garantia de moradia } \\
\text { e transporte gratuitos }\end{array}$ & 23 & 4,5 & 8 & 6,1 & 2 & 2,5 & 1 & 3,7 & 34 & 4,6 \\
\hline $\begin{array}{l}\text { Ser um Programa do } \\
\text { Ministério da Saúde }\end{array}$ & 76 & 15,0 & 24 & 18,3 & 18 & 22,2 & 6 & 22,2 & 124 & 16,6 \\
\hline $\begin{array}{l}\text { Funcionar nos moldes } \\
\text { do Programa de } \\
\text { Saúde da Família }\end{array}$ & 82 & 16,1 & 20 & 15,3 & 14 & 17,3 & 4 & 14,9 & 120 & 16,1 \\
\hline $\begin{array}{l}\text { A experiência de } \\
\text { conhecer outras áreas } \\
\text { do país }\end{array}$ & 87 & 17,1 & 16 & 12,2 & 9 & 11,1 & 6 & 22,2 & 118 & 15,8 \\
\hline $\begin{array}{l}\text { Atuar } \\
\text { profissionalmente } \\
\text { com comunidades } \\
\text { carentes }\end{array}$ & 9 & 1,8 & 1 & 0,8 & 1 & 1,2 & 0 & 0,0 & 11 & 1,5 \\
\hline Total & 508 & 100,0 & 131 & 100,0 & 81 & 100,0 & 27 & 100,0 & 747 & 100,0 \\
\hline
\end{tabular}

*Permitido marcar mais de uma alternativa.

**Corresponde à soma dos grupos 'Desistiu durante o processo seletivo' e 'Desistiu antes de ir para o município'.

Fonte: Maciel Filho, 2007. 
Tabela 3 - Distribuição dos médicos no Pits, por situação no Programa e ano

\begin{tabular}{|c|c|c|c|c|c|c|c|c|}
\hline \multirow{4}{*}{ Ano } & \multicolumn{8}{|c|}{ Situação no Pits } \\
\hline & \multirow{2}{*}{\multicolumn{2}{|c|}{ Inscritos }} & \multicolumn{6}{|c|}{ Aprovados } \\
\hline & & & \multicolumn{2}{|c|}{$\begin{array}{r}\text { Desistiram antes } \\
\text { da lotação }\end{array}$} & \multicolumn{2}{|c|}{ Lotados } & \multicolumn{2}{|c|}{ Total } \\
\hline & $n^{\circ}$ & $\%$ & $n^{\circ}$ & $\%$ & $n^{\circ}$ & $\%$ & $n^{\circ}$ & $\%$ \\
\hline 2001 & 2.284 & 48,9 & 2.095 & 91,7 & 189 & 8,3 & 2.284 & 100,0 \\
\hline 2002 & 1.716 & 36,8 & 1.521 & 88,6 & 195 & 11,4 & 1.716 & 100,0 \\
\hline 2003 & 666 & 14,3 & 581 & 87,2 & 85 & 12,8 & 666 & 100,0 \\
\hline Total & 4.666 & 100,0 & 4.197 & 89,9 & 469 & 10,1 & 4666 & 100,0 \\
\hline
\end{tabular}

Fonte: Maciel Filho, 2007.

Tabela 4 - Distribuição dos médicos que responderam ao questionário e desistiram durante o processo seletivo ou antes de ir para os municípios, segundo os fatores que os levaram a desistir de participar

\begin{tabular}{lrr}
\hline \multirow{2}{*}{ Fatores } & \multicolumn{2}{r}{ Médicos inscritos } \\
\cline { 2 - 3 } & $\mathrm{n}^{\circ}$ & $\%$ \\
\hline Motivos pessoais ou familiares & 90 & 30,8 \\
\hline Outra oportunidade profissional & 96 & 32,9 \\
\hline Receio de não me adaptar à mudança & 35 & 12,0 \\
\hline Não ter obtido classificação para atuar no município ou UF desejados & 29 & 9,6 \\
\hline Falhas na organização do Programa, levando ao descrédito & 43 & 14,7 \\
\hline Total & 293 & 100,0 \\
\hline
\end{tabular}

Fonte: Maciel Filho, 2007.

Ao contrário do que se esperava quando foi formulado, quando se acreditava que atrairia preferencial mente recém-formados, o que se observa é que quase a metade dos inscritos ( $46,7 \%)$ no Pits tinha mais de dez anos de formado, sendo 34,9\% com mais de 15 anos (Tabela 5). Aqueles que desistiram antes da lotação possuíam perfil semelhante, mas os que efetivamente participaram do Programa e chegaram a atuar nos municípios se concentram na faixa de mais de 15 anos de formados $(41,6 \%)$. Esse percentual é cerca de dez pontos percentuais superior ao encontrado no estudo Perfil dos M édicos eEnfermeiros do Programa Saúde 
da Família no Brasil, segundo o qual 32\% dos médicos do PSF têm mais de 15 anos de formados (Machado, 2000).

Tabela 5 - Distribuição dos médicos no Pits, por situação no Programa e tempo de formado - 2001-2003

\begin{tabular}{lrrrrrr}
\hline \multirow{2}{*}{ Tempo de formado } & \multicolumn{7}{c}{ Situação no Pits } \\
\cline { 2 - 8 } & \multicolumn{2}{c}{ Inscritos } & Desistiram antes da lotação & \multicolumn{2}{c}{ Lotados } \\
\cline { 2 - 8 } & $n^{\circ}$ & $\%$ & $n^{\circ}$ & $\%$ & $n^{\circ}$ & $\%$ \\
\hline Menos de 1 ano & 0 & 0,0 & 0 & 0,0 & 0 & 0,0 \\
\hline Entre 1 e 2 anos & 436 & 9,3 & 400 & 9,5 & 38 & 8,1 \\
\hline Mais de 2 a 5 anos & 847 & 18,2 & 763 & 18,2 & 89 & 19,0 \\
\hline Mais de 5 a 10 anos & 998 & 21,4 & 903 & 21,5 & 101 & 21,5 \\
\hline Mais de 10 a 15 anos & 551 & 11,8 & 507 & 12,1 & 46 & 9,8 \\
\hline Mais de 15 anos & 1.631 & 34,9 & 1.447 & 34,5 & 195 & 41,6 \\
\hline Ignorado & 203 & 4,4 & 177 & 4,2 & 0 & 0,0 \\
\hline Total & 4.666 & 100,0 & 4.197 & 100,0 & 469 & 100,0 \\
\hline
\end{tabular}

Fonte: Maciel Filho, 2007.

Conseqüentemente, embora o Programa tenha atraído médicos de todas as idades (Tabela 6), a maioria dos inscritos estava na faixa dos 30 aos 40 anos (36,3\%). Mas quando somadas as faixas etárias acima dos 40 anos, observa-se que quase $40 \%$ dos médicos que se interessaram em participar do Programa ultrapassavam essa faixa de idade. Analisando-se os dois extremos das faixas etárias, verifica-se que os mais jovens (abaixo dos 30 anos) somavam cerca de $23 \%$ e, em contraponto, os que possuíam mais de 50 anos de idade totalizavam 18,6\%.

Em artigo em que faz referência ao primeiro ano de implantação do Pits, Santos destaca esse perfil etário dos médicos que se interessaram em participar do Programa:

Vários milhares de médicos inscreveram-se já no primeiro mês, e o fato que mais chamou a atenção é que por volta de metade dos inscritos são da faixa etária dos 30 aos 50 anos, isto é, quando em situação normal deveriam se encontrar estáveis no apogeu do seu exercício profissional, incluindo os cônjuges e filhos. 0 
grau de insatisfação com a prática médica atual e de disposição para a ruptura com o status quo fica evidente. (Santos, 2001: 147-148)

Na mesma tabela, é possível verificar que mais uma vez esse perfil se repete entre os que desistiram antes da lotação, e é mais acentuado entre os lotados, onde o expressivo percentual de $23,2 \%$ tinham mais de 50 anos.

Esse perfil etário coincide com os achados do estudo Perfil dos M édicos eEnfermeiros do Programa Saúde da Família no Brasil, que revela uma alta concentração de médicos do PSF na faixa entre 30 a 49 anos $(66,62 \%)$ (Machado, 2000). Na faixa mais jovem (de até 29 anos), encontram-se apenas $19,12 \%$ dos médicos do PSF, percentual quase semelhante aos $18,1 \%$ dos médicos lotados no Pits que se encontravam nessa mesma faixa etária.

Tabela 6 - Distribuição dos médicos no Pits, por situação no Programa e faixa etária - 2001-2003

\begin{tabular}{lrrrrrr}
\hline \multirow{2}{*}{ Faixa etária } & \multicolumn{7}{c}{ Situação no Pits } \\
\cline { 2 - 8 } & \multicolumn{2}{c}{ Inscritos } & Desistiram antes da lotação & \multicolumn{2}{c}{ Lotados } \\
\cline { 2 - 8 } & $n^{\circ}$ & $\%$ & $n^{\circ}$ & $\%$ & $n^{\circ}$ & $\%$ \\
\hline Menos de 30 anos & 1.080 & 23,1 & 997 & 23,8 & 85 & 18,1 \\
\hline Entre 30 e 40 anos & 1.689 & 36,3 & 1.532 & 36,5 & 161 & 34,4 \\
\hline Entre 41 e 50 anos & 990 & 21,2 & 879 & 20,9 & 114 & 24,3 \\
\hline Mais de 50 anos & 868 & 18,6 & 762 & 18,2 & 109 & 23,2 \\
\hline Ignorado & 39 & 0,8 & 27 & 0,6 & 0 & 0,0 \\
\hline Total & 4.666 & 100,0 & 4.197 & 100,0 & 469 & 100,0 \\
\hline
\end{tabular}

Fonte: Maciel Filho, 2007.

No caso do Pits, é possível afirmar, pelas mensagens disponíveis no fórum, que parte desses profissionais que se encontravam na faixa etária acima dos 40 anos e possuíam mais de dez anos de formados estando, portanto, no que Machado (1997) denomina 'fase de consolidação profissional' e tendo ultrapassado a 'fase de afirmação profissional' - optaram por atuar no Programa em busca de um estilo de vida mais interiorano e distante do estresse das grandes cidades. 
O lugar onde trabalho tem 9.763 habitantes, são pessoas que ainda têm um certo grau de dignidade, é uma cidade onde você pode sair na rua a qualquer hora da noite ou do dia sem receio algum, onde vocêsai e deixa o portão aberto e às vezes a porta da casa e volta no fim da tarde e está tudo no lugar. Quase todos os dias pela manhã acordo com uma senhora de 76 anos me levando frutas amadurecidas no pé. Onde nunca encontrei uma pessoa pedindo esmola, apesar de toda pobreza que existe; onde na época de caju todos os dias recebo doces variados de presentes; onde na semana santa recebo farinha nativa, tapioca com castanha, beiju; onde no inverno as pessoas deixam milho verde, pamonha e milho assado na minha casa; onde posso armar uma rede na varanda e olhar a lua e sentir a brisa fresquinha e nas noites sem lua ver todas as estrelas e ficar contando os satélites que percorrem o céu; onde abro a porta às cinco horas para pegar abacate, goiaba, acerola, manga e outras frutas. Às vezes me pergunto: mandaram-me para um município muito difícil de viver ou para o paraíso? A solidariedade entre as pessoas étamanha em termos de divisão de comida e de prestar favores aos vizinhos com dificuldade. A religiosidade é outro fato marcante. Sinto como selá fosseo ano inteiro o espírito da solidariedade e não só no Natal, como na civilização. Sinto-me tão bem que agradeço a Deus todos os dias por estar lá. Pra mim foi uma mel hora muito grande na minha qualidade de vida e uma lição de vida atrás da outra. (Fórum Pits)

Tanto os médicos que se inscreveram para participar do Pits quanto os que desistiram antes da lotação e os efetivamente lotados eram, em sua maioria, do sexo masculino (Tabela 7), apresentando percentuais semel hantes aos 55,95\% de médicos homens atuando no PSF, conforme dados da pesquisa de Machado (2000).

Tabela 7 - Distribuição dos médicos no Pits, por situação no Programa e sexo - 20012003

\begin{tabular}{lrrrrrr}
\hline \multirow{2}{*}{ Sexo } & \multicolumn{9}{c}{ Situação no Pits } \\
\cline { 2 - 8 } & \multicolumn{2}{c}{ Inscritos } & Desistiram antes da lotação & \multicolumn{2}{c}{ Lotados } \\
\cline { 2 - 8 } & $\mathrm{n}^{\circ}$ & $\%$ & $\mathrm{n}^{\circ}$ & $\%$ & $\mathrm{n}^{\circ}$ & $\%$ \\
\hline Feminino & 1.892 & 40,6 & 1.686 & 40,2 & 207 & 44,1 \\
\hline Masculino & 2.597 & 55,6 & 2.336 & 55,6 & 262 & 55,9 \\
\hline Ignorado & 177 & 3,8 & 175 & 4,2 & 0 & 0,0 \\
\hline Total & 4.666 & 100,0 & 4.197 & 100,0 & 469 & 100,0 \\
\hline
\end{tabular}

Fonte: Maciel Filho, 2007. 
Cerca de $44 \%$ dos médicos inscritos e dos que desistiram antes da lotação eram casados; já entre os lotados esse percentual sobe para 51\% (Tabela 8).

Tabela 8 - Distribuição dos médicos no Pits, por situação no Programa e estado civil - 2001-2003

\begin{tabular}{lrrrrrr}
\hline \multirow{2}{*}{ Estado civil } & \multicolumn{7}{c}{ Situação no Pits } \\
\cline { 2 - 8 } & \multicolumn{2}{c}{ Inscritos } & Desistiram antes da lotação & \multicolumn{2}{c}{ Lotados } \\
\cline { 2 - 8 } & $\mathrm{n}^{\circ}$ & $\%$ & $\mathrm{n}^{\circ}$ & $\%$ & $\mathrm{n}^{\circ}$ & $\%$ \\
\hline Solteiro & 1.757 & 37,7 & 1.615 & 38,5 & 167 & 35,6 \\
\hline Casado & 2.071 & 44,4 & 1.868 & 44,5 & 239 & 51,0 \\
\hline Separado judicialmente & 226 & 4,8 & 206 & 4,9 & 24 & 5,1 \\
\hline Divorciado & 286 & 6,1 & 255 & 6,1 & 37 & 7,9 \\
\hline Viúvo & 36 & 0,8 & 34 & 0,8 & 2 & 0,4 \\
\hline Ignorado & 290 & 6,2 & 219 & 5,2 & 0 & 0,0 \\
\hline Total & 4.666 & 100,0 & 4.197 & 100,0 & 469 & 100,0 \\
\hline
\end{tabular}

Fonte: Maciel Filho, 2007.

O Pits atraiu médicos provenientes de todos os estados do país, mas com diferenças significativas no grau de interesse demonstrado, particularmente quando essa análise é feita por região (Tabela 9). A maioria residia na Região Sudeste ao se inscrever no Programa (38,0\%), mesma região de origem da maior parte dos que desistiram antes da lotação $(39,7 \%)$. No entanto, os médicos que efetivamente atuaram no Pits eram, em sua maioria, provenientes da Região Nordeste (43,3\%). 0 percentual de médicos lotados que vieram da Região Sudeste foi de pouco mais da metade desse número $(26,2 \%)$, ficando muito próximo do nível registrado pela Região Norte, de onde vieram 19,8\% desses profissionais.

Os médicos das regiões Sul e Centro-Oeste não foram muito atraídos pelo Pits; o percentual de inscritos de cada uma dessas regiões (8,2\% e 7,0\%, respectivamente) ficou abaixo do registrado na Região Norte $(9,1 \%)$, onde há o menor número de médicos do país.

Esses dados mostram que, embora os médicos que residiam na Região Sudeste tenham demonstrado interesse pelo Pits, sendo a região com o maior número de inscritos, também demonstraram dificuldade em atuar no Programa. 
Tabela 9 - Distribuição dos médicos no Pits, por situação no Programa e região de origem - 2001-2003

\begin{tabular}{|c|c|c|c|c|c|c|}
\hline \multirow{3}{*}{ Região de origem } & \multicolumn{6}{|c|}{ Situação no Pits } \\
\hline & \multicolumn{2}{|c|}{ Inscritos } & \multicolumn{2}{|c|}{ Desistiram antes da lotação } & \multicolumn{2}{|c|}{ Lotados } \\
\hline & $n^{\circ}$ & $\%$ & $n^{\circ}$ & $\%$ & $n^{\circ}$ & $\%$ \\
\hline Norte & 428 & 9,1 & 339 & 8,1 & 93 & 19,8 \\
\hline Nordeste & 1.547 & 33,3 & 1.355 & 32,3 & 203 & 43,3 \\
\hline Centro-Oeste & 324 & 7,0 & 301 & 7,2 & 24 & 5,1 \\
\hline Sudeste & 1.783 & 38,0 & 1.668 & 39,7 & 123 & 26,2 \\
\hline Sul & 381 & 8,2 & 357 & 8,5 & 26 & 5,6 \\
\hline Ignorado & 203 & 4,4 & 177 & 4,2 & 0 & 0,0 \\
\hline Total & 4.666 & 100,0 & 4.197 & 100,0 & 469 & 100,0 \\
\hline
\end{tabular}

Fonte: Maciel Filho, 2007.

Dentre os municípios oferecidos para lotação, os médicos inscritos escolheram majoritariamente aqueles localizados na Região Nordeste, com 37,9\% da preferência (Tabela 10). Outros 29,7\% não manifestaram sua preferência para lotação. Em segundo lugar, aparece a Região Norte $(14,7 \%)$, seguida do Sudeste $(11,1 \%)$ e Centro-Oeste $(6,6 \%)$. Essa seqüência da preferência dos médicos pelas respectivas regiões coincidiu com a posição que elas ocupavam em número de municípios para escolha. Assim, como já referido, os 272 municípios contemplados pelo Pits estavam distribuídos pelas regiões da seguinte forma: 46,3\% no Nordeste, $45,2 \%$ no Norte, $5,2 \%$ no Sudeste e 3,3\% no Centro-Oeste. Chama a atenção o fato de que, embora a Região Norte tivesse $45,2 \%$ dos municípios para escolha, apenas $14,7 \%$ dos inscritos se interessaram por eles. Na mesma tabela observa-se que os médicos que chegaram a atuar no Pits foram majoritariamente lotados na Região Nordeste $(59,1 \%)$, responsável por $46,3 \%$ dos municípios disponíveis. A Região Norte, embora contasse com cerca de $45 \%$ dos municípios do Pits, conseguiu lotar apenas $32,2 \%$ dos médicos. No Sudeste foram lotados $6,4 \%$ (para um percentual de 5,2\% de municípios) e o Centro-Oeste contou com uma lotação de 2,5\% dos médicos disponíveis, para cerca de $3 \%$ de municípios. 
Tabela 10 - Distribuição dos médicos no Pits, por situação no Programa e região de preferência para lotação - 2001-2003

\begin{tabular}{lrrrrrr}
\hline \multirow{2}{*}{$\begin{array}{l}\text { Região de } \\
\text { preferência } \\
\text { para lotação }\end{array}$} & \multicolumn{7}{c}{ Situação no Pits } \\
\cline { 2 - 8 } & \multicolumn{2}{c}{ Inscritos } & Desistiram antes da lotação & \multicolumn{2}{c}{ Lotados* } \\
\cline { 2 - 8 } & $\mathrm{n}^{\circ}$ & $\%$ & $\mathrm{n}^{\circ}$ & $\%$ & $\mathrm{n}^{\circ}$ & $\%$ \\
\hline Norte & 688 & 14,7 & 564 & 13,4 & 151 & 32,2 \\
\hline Nordeste & 1.768 & 37,9 & 1.533 & 36,6 & 277 & 59,1 \\
\hline Centro-Oeste & 307 & 6,6 & 295 & 7,0 & 12 & 2,5 \\
\hline Sudeste & 516 & 11,1 & 481 & 11,5 & 29 & 6,2 \\
\hline Ignorado & 1.387 & 29,7 & 1.324 & 31,5 & 0 & 0,0 \\
\hline Total & 4.666 & 100,0 & 4.197 & 100,0 & 469 & 100,0 \\
\hline
\end{tabular}

* No caso dos lotados, refere-se à região de lotação.

Fonte: Maciel Filho, 2007.

Tabela 11 - Distribuição dos médicos lotadosno Pits, por ano e situação no Programa, em relação ao total de lotados no período 2001-2003

\begin{tabular}{|c|c|c|c|c|c|c|c|c|}
\hline \multirow{3}{*}{ Situação no Pits } & \multicolumn{6}{|c|}{ Ano } & \multirow{2}{*}{\multicolumn{2}{|c|}{ Total }} \\
\hline & \multicolumn{2}{|c|}{2001} & \multicolumn{2}{|c|}{2002} & \multicolumn{2}{|c|}{2003} & & \\
\hline & $n^{0}$ & $\%$ & $n^{0}$ & $\%$ & $n^{0}$ & $\%$ & $n^{0}$ & $\%$ \\
\hline \multirow[t]{2}{*}{ Lotados } & 189 & 40,3 & 195 & 41,6 & 85 & 18,1 & 469 & 100,0 \\
\hline & \multicolumn{8}{|c|}{ Situação dos lotados } \\
\hline $\begin{array}{l}\text { Concluíram } 1 \text { ano de } \\
\text { participação }\end{array}$ & 78 & 16,2 & 96 & 19,9 & 49 & 10,2 & 223 & 46,3 \\
\hline $\begin{array}{l}\text { Renovaram a participação } \\
\text { por mais } 1 \text { ano }\end{array}$ & 11 & 2,3 & 18 & 3,7 & 8 & 1,7 & 37 & 7,7 \\
\hline $\begin{array}{l}\text { Desistiram ou foram } \\
\text { desligados }\end{array}$ & 105 & 21,8 & 85 & 17,6 & 32 & 6,6 & 222 & 46,0 \\
\hline Total & 194 & 40,2 & 199 & 41,3 & 89 & 18,5 & $482 *$ & 100,0 \\
\hline
\end{tabular}

* Total superior ao de lotados pelo fato de um mesmo médico poder estar em mais de uma situação.

Fonte: Maciel Filho, 2007.

As tabelas 11 e 12 resumem o que ocorreu com os 469 médicos lotados, no período 2001 a 2003. Ao longo dos três anos, 46,3\% concluíram um ano de participação no Programa, mas os desistentes e desligados alcançaram praticamente o mesmo percentual (46\%). Mais 
da metade dos médicos lotados em 2001 desistiram ou foram desligados $(54,1 \%)$. Nos anos seguintes, esse percentual diminuiu, mas ainda se manteve em patamares expressivos ( 42,7\% em 2002 e 36\% em 2003). E somente em 2003 o percentual de desistentes foi substancialmente inferior ao dos que chegaram a concluir um ano de atuação no Pits ( $36 \%$ contra $55 \%$, respectivamente).

Tabela 12 - Distribuição dos médicos lotados no Pits, por ano e situação no Programa, em relação ao total de lotados a cada ano

\begin{tabular}{lrrr}
\hline & \multicolumn{3}{c}{ Ano } \\
\cline { 2 - 4 } Situação no Pits & 2001 & 2002 & 2003 \\
\cline { 2 - 4 } & $\%$ & $\%$ & $\%$ \\
\hline Concluíram 1 ano de participação/ lotados no ano & 40,2 & 48,3 & 55,0 \\
\hline Renovaram a participação por mais 1 ano/ lotados no ano & 5,7 & 9,0 & 9,0 \\
\hline Desistiram ou foram desligados/ lotados no ano & 54,1 & 42,7 & 36,0 \\
\hline Total & 100,0 & 100,0 & 100,0 \\
\hline
\end{tabular}

Fonte: Maciel Filho, 2007.

As constantes desistências e desligamentos de profissionais abatiam os que ficavam e acarretavam transtornos para o desempenho das atividades, como mostram algumas mensagens disponíveis no fórum virtual do Pits:

Aproveitamos o espaço, para externar nosso profundo pesar, com a perda de alguns companheiros, que, no limite de sua resistência, após esgotarem todas as possibilidades de diálogo, e não vislumbrando alternativa, infelizmente, optaram por 'abandonar o barco'. Alguns poderão, numa primeira leitura, reputar o 'abandonar o barco' como um ato der ebel dia ou, quem sabe, fraqueza daqueles que se foram. Se o fizeram, por certo, foram vítimas de um ledo engano. Foi sim, antes detudo, um ato decoerência. ( ...) Talvez, nessemomento, devêssemos refletir por quealguns persistem. Por necessidade? Por acomodação? Por alienação? Por ousadia ou pertinácia? (...) Louvo os que partiram, mas permito-melouvar a muitos que ficaram, eque, como eu, acreditam quetodos os caminhos têm mais de uma direção. E às vezes é necessário ficar. Nem que seja para honrar os companheiros que se foram. (Fórum Pits)

no muniápio em que estou, em dezembro foram embora duas médicas e uma enfermeira, ficando uma equipe completa e uma enfermeira sozinha. Isso prejudica muito o desenvolvimento dos programas, pois todo o resto da área descoberta migra para nosso posto de atendimento. Não existem 
outros profissionais contratados pela prefeitura enão podemos nos recusar a atender, causando uma sobrecarga de trabalho eatrapalhando toda a nossa demanda que estava organizada. Peço a (...) quem de direito que ligue para a secretária ou a coordenadora do município para ver o que pode ser feito, pois estamos angustiados sem saber como fazer. (Fórum Pits)

\section{Outras mensagens ressaltam os motivos que levaram os médicos a desistir; algumas são de autoria dos próprios desistentes:}

É lamentável (...), pois estamos perdendo os nossos colegas, (...) é uma pena, pois isto tudo está acontecendo em decorrência da falta de valorização que os gestores municipais e de saúde impõem aos profissionais, como falta de pagamento da contrapartida efalta de condições para setrabalhar. (Fórum Pits)

Queridos amigos, colegas, desconhecidos, tutores, coordenadores nacionais e todo pessoal envolvido com o Pits:

Desde fevereiro assumi a diretoria de uma casa asilar (...). Quando fui convidada, entrei em contato com a coordenação Estadual (...). . Na ocasião, levei um documento, sol icitando o desligamento edisse que estava de saída, mesmo ganhando menos, para estar mais próxima de minha família, pois tendo 48 anos, as viagens (...) em estradas de difícil acesso, sem segurança alguma (...), demorando muitas vezes, entre a distância e aguardar condução, 12 a 15 horas (...) Hoje meu salário éa metade do que ganhava no Pits, mas estou perto do meu filho e marido, estou feliz, estou fazendo um curso de inglês para fazer a prova demestrado (...), einteriormente em paz por ter participado e trabalhado por melhores índices (...). Saio do Programa de cabeça erguida, sem ser conivente com profissionais que vão uma vez por semana para o interior, sem ser conivente com profissionais que trabalham em hospitais da capital (...), sem ser conivente com profissionais que passam 15 dias na capital e 1 no interior, mas têm uma lábia com seus gestores e vão conseguindo levar. Tenho um novo desafio, desenvolver uma nova política de atuação junto aos idosos. (...) A todos que ficam, boa sorte! (Fórum Pits)

O regulamento do Pits previa, desde o primeiro processo seletivo, que o período de exercício dos profissionais seria de um ano renovável por mais um. Anal isando-se os bancos de dados do Programa, verifica-se que, ao longo dos três anos de atividade do Pits, somente 37 dos 469 médicos que chegaram a atuar efetivamente nos municípios prorrogaram sua participação por um ano ou mais, o que representa um percentual de 7,7\%. Esse dado, aliado aos expressivos percentuais de desistência ou desligamento, é convergente com o estudo de Machado (2000), segundo o qual o tempo médio de permanência de grande parte dos médicos no PSF é de menos de um ano. 
Tabela 13 - Distribuição de médicos lotados no Pits, por situação e região e UF de lotação, em relação ao total de lotados do Programa, no período 2001-2003

\begin{tabular}{|c|c|c|c|c|c|c|c|c|c|}
\hline \multirow{3}{*}{$\begin{array}{l}\text { Região de } \\
\text { lotação }\end{array}$} & \multirow{3}{*}{ UF } & \multicolumn{8}{|c|}{ Situação no Pits } \\
\hline & & \multicolumn{2}{|c|}{$\begin{array}{r}\text { Concluíram } \\
\text { um ano de } \\
\text { participação }\end{array}$} & \multicolumn{2}{|c|}{$\begin{array}{r}\text { Renovaram } \\
\text { a participação } \\
\text { por mais } 1 \text { ano }\end{array}$} & \multicolumn{2}{|c|}{$\begin{array}{r}\text { Desistiram } \\
\text { ou foram } \\
\text { desligados }\end{array}$} & \multicolumn{2}{|c|}{ Total } \\
\hline & & $n^{0}$ & $\%$ & $n^{0}$ & $\%$ & $n^{0}$ & $\%$ & $n^{0}$ & $\%$ \\
\hline \multirow{7}{*}{ Norte } & $A C$ & 13 & 2,7 & 0 & 0,0 & 12 & 2,5 & 25 & 5,2 \\
\hline & $\mathrm{AP}$ & 9 & 1,9 & 3 & 0,6 & 7 & 1,5 & 19 & 3,9 \\
\hline & $A M$ & 6 & 1,2 & 2 & 0,4 & 9 & 1,9 & 17 & 3,5 \\
\hline & $\mathrm{PA}$ & 35 & 7,3 & 2 & 0,4 & 27 & 5,6 & 64 & 13,3 \\
\hline & RO & 3 & 0,6 & 0 & 0,0 & 3 & 0,6 & 6 & 1,2 \\
\hline & $\mathrm{RR}$ & 2 & 0,4 & 0 & 0,0 & 0 & 0,0 & 2 & 0,4 \\
\hline & TO & 7 & 1,5 & 2 & 0,4 & 11 & 2,3 & 20 & 4,1 \\
\hline \multicolumn{2}{|l|}{ Subtotal } & 75 & 15,6 & 9 & 1,8 & 69 & 14,4 & 153 & 31,6 \\
\hline \multirow{9}{*}{ Nordeste } & $\mathrm{AL}$ & 3 & 0,6 & 6 & 1,2 & 1 & 0,2 & 10 & 2,1 \\
\hline & $\mathrm{BA}$ & 24 & 5,0 & 3 & 0,6 & 20 & 4,1 & 47 & 9,8 \\
\hline & CE & 17 & 3,5 & 2 & 0,4 & 31 & 6,4 & 50 & 10,4 \\
\hline & MA & 43 & 8,9 & 5 & 1,0 & 40 & 8,3 & 88 & 18,3 \\
\hline & PB & 12 & 2,5 & 3 & 0,6 & 13 & 2,7 & 28 & 5,8 \\
\hline & $\mathrm{PE}$ & 12 & 2,5 & 2 & 0,4 & 13 & 2,7 & 27 & 5,6 \\
\hline & $\mathrm{PI}$ & 1 & 0,2 & 0 & 0,0 & 2 & 0,4 & 3 & 0,6 \\
\hline & RN & 10 & 2,1 & 2 & 0,4 & 12 & 2,5 & 24 & 5,0 \\
\hline & SE & 3 & 0,6 & 3 & 0,6 & 5 & 1,0 & 11 & 2,3 \\
\hline \multirow[t]{2}{*}{ Subtotal } & & 125 & 25,9 & 26 & 5,2 & 137 & 28,3 & 288 & 59,9 \\
\hline & GO & 2 & 0,4 & 0 & 0,0 & 1 & 0,2 & 3 & 0,6 \\
\hline \multirow[t]{2}{*}{ Centro-Oeste } & MT & 5 & 1,0 & 0 & 0,0 & 1 & 0,2 & 6 & 1,2 \\
\hline & MS & 1 & 0,2 & 0 & 0,0 & 2 & 0,4 & 3 & 0,6 \\
\hline Subtotal & & 8 & 1,6 & 0 & 0,0 & 4 & 0,8 & 12 & 2,4 \\
\hline Sudeste & MG & 15 & 3,1 & 2 & 0,4 & 12 & 2,5 & 29 & 6,0 \\
\hline Subtotal & & 15 & 3,1 & 2 & 0,4 & 12 & 2,5 & 29 & 6,0 \\
\hline Brasil & & 223 & 46,3 & 37 & 7,7 & 222 & 46,0 & 482 & 100,0 \\
\hline
\end{tabular}

Fonte: Maciel Filho, 2007. 
O baixo percentual de profissionais que optaram por renovar sua participação no Programa mostra que nem mesmo o incentivo criado pelo Ministério da Saúde para este fim foi capaz de ampliar o tempo de permanência dos médicos. 0 incentivo previa um acréscimo de $10 \%$ do valor da bolsa, a título de estímulo de permanência, para os profissionais que decidiam continuar.

A distribuição dos médicos que chegaram a ir para os municípios, por UF de lotação, é apresentada na Tabela 13. Com base nela podemos observar que os estados a registrar o maior percentual de médicos que concluíram um ano de participação no Programa, em relação ao total de lotados em todos os estados, foram o Maranhão (8,9\%), o Pará (7,3\%) ea Bahia (5\%).

Seixase Stella (2002), que coordenaram o Programa durante grande parte de sua vigência, destacam que, no ano de 2002, os estados do Amazonas, Amapá e Piauí apresentaram os mais baixos percentuais de lotação de médicos, tendo menos de $10 \%$ de suas vagas preenchidas. A Tabela 13 realmente reforça a afirmação desses autores, mas revela que 0 baixo percentual de adesão obtido por estes estadoséainda mais acentuado. Nela se observa que, ao longo de 2001 a 2003, estes estados mais uma vez aparecem entre os de mais baixo percentual de lotação, que foram Roraima $(0,4 \%)$, Piauí $(0,6 \%)$, Rondônia (1,2\%), Amazonas (3,5\%) e Amapá $(3,9 \%)$.

Embora outros estados também apresentem baixos percentuais, não se enquadram na mesma condição, uma vez que, nesses casos, o que determina o baixo percentual de lotação é o baixo número de vagas oferecidas. ${ }^{10}$

As respostas do questionário aplicado pelo estudo da Rede Observatório confirmam a maior lotação de médicos nos municípios da Região Nordeste (Tabela 14). A mesma tabela revela que mais da metade daqueles que desistiram depois de já estarem atuando no Pits, e que responderam ao questionário, estavam lotados na Região Norte (50,2\%), confirmando a baixa capacidade dessa região para fixar profissionais.

10 Como já referido, as permanentes mudanças na lista de municípios participantes não permitiram a construção de um quadro com o número de vagas disponíveis em cada município, que variou bastante ao longo dos três anos de vigência do Pits, conforme registros dos bancos de dados do Programa. 
Tabela 14 - Distribuição dos médicos que responderam ao questionário, segundo situação no Pits e região onde atuaram por mais tempo

\begin{tabular}{|c|c|c|c|c|c|c|c|c|c|c|}
\hline \multirow{3}{*}{$\begin{array}{l}\text { Região de } \\
\text { atuação* }\end{array}$} & \multicolumn{10}{|c|}{ Situação no Pits } \\
\hline & \multicolumn{2}{|c|}{$\begin{array}{r}\text { Desistiram } \\
\text { antes de } \\
\text { atuar** }\end{array}$} & \multicolumn{2}{|c|}{$\begin{array}{r}\text { Atuam ou } \\
\text { concluíram sua } \\
\text { participação }\end{array}$} & \multicolumn{2}{|c|}{$\begin{array}{r}\text { Desistiram } \\
\text { depois de } \\
\text { estar atuando }\end{array}$} & \multicolumn{2}{|c|}{ Desligados } & \multicolumn{2}{|c|}{ Total } \\
\hline & $n^{\circ}$ & $\%$ & $n^{0}$ & $\%$ & $n^{\circ}$ & $\%$ & $n^{0}$ & $\%$ & $\mathrm{n}^{\circ}$ & $\%$ \\
\hline Norte & 53 & 27,0 & 15 & 35,7 & 13 & 50,2 & 4 & 36,4 & 85 & 30,9 \\
\hline Nordeste & 81 & 41,3 & 18 & 42,8 & 10 & 38,4 & 6 & 54,5 & 115 & 41,8 \\
\hline Centro-Oeste & 13 & 6,6 & 4 & 9,6 & 2 & 7,6 & 1 & 9,1 & 20 & 7,3 \\
\hline Sudeste & 13 & 6,6 & 2 & 4,8 & 1 & 3,8 & 0 & 0,0 & 16 & 5,8 \\
\hline Ignorado & 36 & 18,4 & 3 & 7,1 & 0 & 0,0 & 0 & 0,0 & 39 & 14,2 \\
\hline Total & 196 & 100,0 & 42 & 100,0 & 26 & 100,0 & 11 & 100,0 & 275 & 100,0 \\
\hline
\end{tabular}

* Neste caso, refere-se à região que o profissional escolheu para atuar.

** Corresponde à soma dos grupos 'Desistiu durante o processo sel etivo' e 'Desistiu antes de ir para o município'.

Fonte: Maciel Filho, 2007.

Conhecer e comparar o perfil dos profissionais que se enquadram em cada uma das três situações analisadas ('concluíram um ano de participação'; 'renovaram a participação por mais 1 ano'; 'desistiram ou foram desligados') ajuda a compreender essas variações no grau de adesão ao Pits e aos respectivos municípios. A maioria dos médicos que concluíram um ano ou renovaram sua participação por um ano ou mais era proveniente das regiões Nordeste e Norte, como mostra a Tabela 15 (a soma das duas regiões como origem dos profissionais desses dois grupos totaliza 68,7\% e 73\%, respectivamente). Entre os desistentes/ desligados, esse percentual cai para 56,3\%. Cerca de 33\% dos desistentes ou desligados vieram da Região Sudeste.

A distribuição por UF, disponível na Tabela 16, mostra que a maioria dos médicos desistentes/ desligados era proveniente dos estados do Rio de J aneiro (14,8\%), Pará (11,2\%) e São Paulo (10,7\%). Somando-se os percentuais do Rio de Janeiro e de São Paulo, verifica-se que aproximadamente $26 \%$ dos médicos que desistiram ou foram desligados do Pits vieram desses dois estados do Sudeste. 
Tabela 15 - Distribuição dos médicos lotados no Pits, por situação no Programa e região de origem - 2001-2003

\begin{tabular}{lrrrrrr}
\hline \multirow{2}{*}{ Região de origem } & \multicolumn{7}{c}{ Situação no Pits } \\
\cline { 2 - 8 } & $\begin{array}{r}\text { Concluíram um ano } \\
\text { de participação }\end{array}$ & $\begin{array}{r}\text { Renovaram a participação } \\
\text { por mais 1 ano }\end{array}$ & $\begin{array}{r}\text { Desistiram ou } \\
\text { foram desl igados }\end{array}$ \\
\cline { 2 - 8 } Norte & 55 & 24,6 & 6 & 16,2 & 35 & 15,9 \\
\hline Nordeste & 98 & 44,1 & 21 & 56,8 & 90 & 40,4 \\
\hline Centro-Oeste & 12 & 5,3 & 1 & 2,7 & 11 & 5,1 \\
\hline Sudeste & 48 & 21,6 & 7 & 18,9 & 73 & 32,7 \\
\hline Sul & 10 & 4,4 & 2 & 5,4 & 13 & 5,9 \\
\hline Total & 223 & 100,0 & 37 & 100,0 & 222 & 100,0 \\
\hline
\end{tabular}

Fonte: Maciel Filho, 2007.

Comparando-se as tabelas 16 e 17 é possível observar que a participação do Rio de J aneiro e de São Paulo como estados de origem dos lotados foi de 12,4\% e 7\%; já entre os que renovaram sua participação no Programa não ultrapassou os $8,1 \%$ (no caso do Rio de Janeiro), não havendo médico oriundo de São Paulo que tenha optado por renovar a permanência. Assim, Rio de J aneiro e São Paulo destacaram-se mais como origem de médicos desistentes/ desligados do que de lotados ou dos que prorrogaram sua atuação. Esses dados parecem demonstrar a existência de maior dificuldade de adaptação dos médicos desses dois estados em atuar nos municípios contemplados pelo Programa.

Além da maior facilidade de adaptação dos médicos originários das regiões Norte e Nordeste, percebe-se, por mensagens disponíveis no fórum virtual, que esses profissionais se mostram particularmente sensibilizados com as condições de vida e saúde da população de seus estados e regiões:

Sou profissional do Maranhão, um dos estados mais pobres da Região Nordeste, sou conhecedora dos problemas aqui existentes ede como os colegas pitianos de outras regiões deste país contribuíram para tornar o meu estado eminha região mais assistida e consciente sobre os problemas de saúde que afetam minha gente; falo aqui em nome da minha comunidade e de todos aqueles que reconhecem o trabalho humanizado desenvolvido por todos os colegas deste projeto tão grandioso e importante:

- as crianças que deixaram de morrer por diarréia, desnutrição, IRA;

- as crianças vacinadas e acompanhadas por profissionais qualificados e comprometidos com o seu país; 
- a assistência dispensada aos grupos de idosos, gestantes, hipertensos, diabéticos, adolescentes;

- a informação e a atenção dadas aos municípios e à população tão pobre deste estado, que talvez nunca teriam o privilégio de conviver com pessoas tão solidárias e empenhadas com o trabalho em saúde;

- pelos maranhenses que vieram ao mundo tão bem assistidos e orientados, sendo garantido seu direito à vida ea possibilidade delutar por um paísmelhor;

- o carinho oferecido a todos os indivíduos, sejam eles brancos, negros, índios, crianças e idosos;

Falo dos maranhenses por ser a terra onde vivo, mas estendo a todas as equipes lotadas em regiões emunićpios detão difícil acesso como nas reservas indígenas, nas áreas de ilhas, nas regiões ribeirinhas, enfim nos rincões deste tão maravilhoso e rico Brasil. Agradeço a Deus por ter conhecido pessoas maravilhosas, agradeço por ter participado deste programa, agradeço a cada médico e a cada enfermeiro que com coragem e espírito solidário ajudaram gente tão simples e tão humilde (...). (Fórum Pits)

A Tabela 18 revela que a maioria dos médicos que concluíram um ano ou renovaram sua participação graduou-se na Região Nordeste (41,7\% e 67,6\%, respectivamente), e embora ela seja também a região onde se graduou o maior percentual de desistentes ou desligados (40,4\%), observa-se que é a Região Sudeste que se destaca nesse aspecto. Isso porque, enquanto a Região Nordeste é a região de graduação da maioria dos lotados, dos que concluíram um ano de participação, dos que renovaram por mais um ano e dos que desistiram ou foram desligados, 0 Sudeste apresenta um índice como região de graduação dos desistentes ou desligados (37,4\%) bastante superior à sua participação como região de graduação dos que concluíram um ano $(25,6 \%)$ ou renovaram $(16,2 \%)$.

Também deve ser destacado o expressivo percentual de 19,7\% dos médicos que concluíram um ano no Pits e que se formou em instituições de ensino superior da Região Norte, que, como vimos, é a região de origem de $19,8 \%$ dos lotados. Isso faz supor que os médicos oriundos dessa região concluíram ali mesmo sua graduação. Esse dado é relevante, porque aponta uma tendência de interesse de fixação, por parte desses médicos, na própria região onde habitam, tão carente dessa categoria profissional. E torna-se ainda mais relevante quando lembramos que até há poucos anos a maioria desses profissionais precisaria deslocarse para as demais regiões - particularmente o Sudeste e o Sul - para se graduar em medicina. 
Tabela 16 - Distribuição dos médicos lotados no Pits, por situação no Programa e região e Unidade da Federação de origem - 2001-2003

\begin{tabular}{|c|c|c|c|c|c|c|c|}
\hline \multirow{3}{*}{$\begin{array}{l}\text { Região de } \\
\text { lotação }\end{array}$} & \multirow{3}{*}{ UF } & \multicolumn{6}{|c|}{ Situação no Pits } \\
\hline & & \multicolumn{2}{|c|}{$\begin{array}{l}\text { Concluíram } \\
1 \text { ano de } \\
\text { participação }\end{array}$} & \multicolumn{2}{|c|}{$\begin{array}{r}\text { Renovaram } \\
\text { a participação } \\
\text { por mais } 1 \text { ano }\end{array}$} & \multicolumn{2}{|c|}{$\begin{array}{r}\text { Desistiram } \\
\text { ou foram } \\
\text { desligados }\end{array}$} \\
\hline & & $n^{0}$ & $\%$ & $\mathrm{n}^{\circ}$ & $\%$ & $n^{0}$ & $\%$ \\
\hline \multirow{7}{*}{ Norte } & $A C$ & 9 & 4,0 & 1 & 2,7 & 3 & $\overline{1,4}$ \\
\hline & $A P$ & 5 & 2,2 & 0 & 0,0 & 1 & 0,5 \\
\hline & AM & 2 & 0,9 & 0 & 0,0 & 3 & $\overline{1,4}$ \\
\hline & PA & 36 & 16,2 & 3 & 8,1 & 25 & 11,2 \\
\hline & RO & 2 & 0,9 & 0 & 0,0 & 1 & 0,5 \\
\hline & RR & 1 & 0,4 & 0 & 0,0 & 0 & $\overline{0,0}$ \\
\hline & TO & 0 & 0,0 & 2 & 5,4 & 2 & 0,9 \\
\hline \multicolumn{2}{|l|}{ Subtotal } & 55 & 24,6 & 6 & 16,2 & 35 & 15,9 \\
\hline \multirow{9}{*}{ Nordeste } & $\mathrm{AL}$ & 6 & 2,7 & 11 & 29,8 & 9 & 4,1 \\
\hline & $\mathrm{BA}$ & 21 & 9,5 & 5 & 13,5 & 14 & 6,2 \\
\hline & $\mathrm{CE}$ & 17 & 7,6 & 2 & 5,4 & 19 & 8,5 \\
\hline & $\mathrm{MA}$ & 22 & 10,0 & 2 & 5,4 & 20 & 8,9 \\
\hline & PB & 10 & 4,5 & 1 & 2,7 & 12 & 5,4 \\
\hline & $\mathrm{PE}$ & 11 & 4,9 & 0 & 0,0 & 7 & 3,2 \\
\hline & $\mathrm{PI}$ & 2 & 0,9 & 0 & 0,0 & 1 & 0,5 \\
\hline & $\mathrm{RN}$ & 8 & 3,6 & 0 & 0,0 & 4 & 1,8 \\
\hline & SE & 1 & 0,4 & 0 & 0,0 & 4 & $\overline{1,8}$ \\
\hline \multicolumn{2}{|l|}{ Subtotal } & 98 & 44,1 & 21 & 56,8 & 90 & 40,4 \\
\hline \multirow{4}{*}{ Centro-Oeste } & DF & 8 & 3,6 & 0 & 0,0 & 6 & 2,7 \\
\hline & GO & 1 & 0,4 & 1 & 2,7 & 1 & 0,5 \\
\hline & MT & 1 & 0,4 & 0 & 0,0 & 1 & 0,5 \\
\hline & MS & 2 & 0,9 & 0 & 0,0 & 3 & $\overline{1,4}$ \\
\hline \multicolumn{2}{|l|}{ Subtotal } & 12 & 5,3 & 1 & 2,7 & 11 & $\overline{5,1}$ \\
\hline \multirow{4}{*}{ Sudeste } & ES & 2 & 0,9 & 2 & 5,4 & 4 & 1,8 \\
\hline & MG & 11 & 4,9 & 2 & 5,4 & 12 & 5,4 \\
\hline & $\mathrm{RJ}$ & 25 & 11,3 & 3 & 8,1 & 33 & 14,8 \\
\hline & $\mathrm{SP}$ & 10 & 4,5 & 0 & 0,0 & 24 & 10,7 \\
\hline \multirow[t]{2}{*}{ Subtotal } & & 48 & 21,6 & 7 & 18,9 & 73 & 32,7 \\
\hline & PR & 3 & 1,3 & 0 & 0,0 & 2 & 0,9 \\
\hline \multirow[t]{2}{*}{ Sul } & $\mathrm{SC}$ & 3 & 1,3 & 0 & 0,0 & 4 & 1,8 \\
\hline & RS & 4 & 1,8 & 2 & 5,4 & 7 & 3,2 \\
\hline \multicolumn{2}{|l|}{ Subtotal } & 10 & 4,4 & 2 & 5,4 & 13 & 5,9 \\
\hline \multicolumn{2}{|l|}{ Brasil } & 223 & 100,0 & 37 & 100,0 & 222 & 100,0 \\
\hline
\end{tabular}

Fonte: Maciel Filho, 2007. 
Tabela 17 - Distribuição dos médicos no Pits, por situação no Programa, região e UF de origem - 2001-2003

\begin{tabular}{|c|c|c|c|c|c|c|c|}
\hline \multirow{3}{*}{$\begin{array}{c}\text { Região de } \\
\text { origem }\end{array}$} & \multirow{3}{*}{$\begin{array}{l}\text { UF de } \\
\text { origem }\end{array}$} & \multicolumn{6}{|c|}{ Situação no Pits } \\
\hline & & \multicolumn{2}{|c|}{ Inscritos } & \multicolumn{2}{|c|}{$\begin{array}{r}\text { Desistiram } \\
\text { antes da lotação }\end{array}$} & \multicolumn{2}{|c|}{ Lotados } \\
\hline & & $n^{0}$ & $\%$ & $n^{0}$ & $\%$ & $n^{0}$ & $\%$ \\
\hline \multirow{7}{*}{ Norte } & $\mathrm{AC}$ & 57 & 1,2 & 45 & 1,1 & 13 & 2,8 \\
\hline & $A P$ & 20 & 0,4 & 17 & 0,4 & 3 & 0,6 \\
\hline & AM & 46 & 1,0 & 38 & 0,9 & 9 & 1,9 \\
\hline & PA & 253 & 5,4 & 194 & 4,6 & 61 & 13,1 \\
\hline & RO & 21 & 0,5 & 18 & 0,4 & 3 & 0,6 \\
\hline & $\mathrm{RR}$ & 11 & 0,2 & 10 & 0,2 & 1 & 0,2 \\
\hline & TO & 20 & 0,4 & 17 & 0,4 & 3 & 0,6 \\
\hline \multicolumn{2}{|l|}{ Subtotal } & 428 & 9,1 & 339 & 8,1 & 93 & 19,8 \\
\hline \multirow{9}{*}{ Nordeste } & $\mathrm{AL}$ & 115 & 2,5 & 93 & 2,2 & 24 & 5,1 \\
\hline & BA & 284 & 6,1 & 247 & 5,9 & 39 & 8,3 \\
\hline & CE & 209 & 4,5 & 175 & 4,2 & 36 & 7,7 \\
\hline & MA & 173 & 3,7 & 132 & 3,1 & 43 & 9,2 \\
\hline & PB & 304 & 6,5 & 282 & 6,7 & 23 & 4,9 \\
\hline & PE & 294 & 6,3 & 277 & 6,6 & 18 & 3,8 \\
\hline & $\mathrm{PI}$ & 35 & 0,8 & 32 & 0,8 & 3 & 0,6 \\
\hline & RN & 105 & 2,3 & 94 & 2,2 & 12 & 2,6 \\
\hline & SE & 28 & 0,6 & 23 & 0,5 & 5 & 1,1 \\
\hline \multicolumn{2}{|l|}{ Subtotal } & 1.547 & 33,3 & 1.355 & 32,3 & 203 & 43,3 \\
\hline \multirow{4}{*}{ Centro-Oeste } & $\mathrm{DF}$ & 135 & 2,9 & 122 & 2,9 & 14 & 3,0 \\
\hline & GO & 120 & 2,6 & 117 & 2,8 & 3 & 0,6 \\
\hline & MT & 28 & 0,6 & 25 & 0,6 & 3 & 0,6 \\
\hline & MS & 41 & 0,9 & 37 & 0,9 & 4 & 0,9 \\
\hline \multirow[t]{2}{*}{ Subtotal } & & 324 & 7,0 & 301 & 7,2 & 24 & 5,1 \\
\hline & ES & 63 & 1,4 & 56 & 1,3 & 7 & 1,5 \\
\hline \multirow{3}{*}{ Sudeste } & $M G$ & 310 & 6,6 & 287 & 6,8 & 25 & 5,3 \\
\hline & RJ & 746 & 15,9 & 691 & 16,5 & 58 & 12,4 \\
\hline & SP & 664 & 14,1 & 634 & 15,1 & 33 & 7,0 \\
\hline \multirow[t]{2}{*}{ Subtotal } & & 1.783 & 38,0 & 1.668 & 39,7 & 123 & 26,2 \\
\hline & PR & 116 & 2,5 & 111 & 2,6 & 5 & 1,1 \\
\hline \multirow[t]{2}{*}{ Sul } & SC & 93 & 2,0 & 85 & 2,0 & 13 & 2,8 \\
\hline & RS & 172 & 3,7 & 161 & 3,8 & 8 & 1,7 \\
\hline Subtotal & & 381 & 8,2 & 357 & 8,5 & 26 & 5,6 \\
\hline Ignorado & & 203 & 4,4 & 177 & 4,2 & 0 & 0,0 \\
\hline Brasil & & 223 & 100,0 & 37 & 100,0 & 222 & 100,0 \\
\hline
\end{tabular}

Fonte: Maciel Filho, 2007. 
Como ressaltam Vieira et al. (2004: 192):

a distribuição de cursos e de vagas retrata as desigualdades espaciais do ensino em medicina (...). Pode-se dizer que a expansão dos cursos no Sudeste e no Sul obedeceu muito mais ao desenvolvimento econômico e ao poder de compra dessas regiões do que às reais necessidades de acesso ao ensino superior nas regiões desprovidas de infra-estrutura como o Norte e o Nordeste.

Tabela 18 - Distribuição dos médicos lotados no Pits, por situação no Programa e região de graduação - 2001-2003

\begin{tabular}{lrrrrrr}
\hline \multirow{2}{*}{ Região de origem } & \multicolumn{7}{c}{ Situação no Pits } \\
\cline { 2 - 8 } & $\begin{array}{r}\text { Concluíram 1 ano } \\
\text { de participação }\end{array}$ & $\begin{array}{r}\text { Renovaram a participação } \\
\text { por mais 1 ano }\end{array}$ & $\begin{array}{r}\text { Desistiram ou } \\
\text { foram desligados }\end{array}$ \\
\cline { 2 - 8 } Norte & $\mathrm{n}^{\circ}$ & $\%$ & $\mathrm{n}^{\circ}$ & $\%$ & $\mathrm{n}^{\circ}$ & $\%$ \\
\hline Nordeste & 44 & 19,7 & 2 & 5,4 & 31 & 14,0 \\
\hline Centro-Oeste & 93 & 41,7 & 25 & 67,6 & 90 & 40,4 \\
\hline Sudeste & 2 & 0,9 & 2 & 5,4 & 5 & 2,3 \\
\hline Sul & 57 & 25,6 & 6 & 16,2 & 83 & 37,4 \\
\hline Exterior & 15 & 6,7 & 2 & 5,4 & 11 & 5,0 \\
\hline Total & 12 & 5,4 & 0 & 0,0 & 2 & 0,9 \\
\hline
\end{tabular}

Fonte: Maciel Filho, 2007.

Tabela 19 - Distribuição dos médicos lotados no Pits, por situação no Programa e sexo - 2001-2003

\begin{tabular}{lrrrrrr}
\hline \multirow{2}{*}{ Sexo } & \multicolumn{7}{c}{ Situação no Pits } \\
\cline { 2 - 7 } & $\begin{array}{r}\text { Concluíram 1 ano } \\
\text { de participação }\end{array}$ & $\begin{array}{r}\text { Renovaram a participação } \\
\text { por mais 1 ano }\end{array}$ & $\begin{array}{r}\text { Desistiram ou } \\
\text { foram desl igados }\end{array}$ \\
\cline { 2 - 8 } & $\mathrm{n}^{\circ}$ & $\%$ & $\mathrm{n}^{\circ}$ & $\%$ & $\mathrm{n}^{\circ}$ & $\%$ \\
\hline Feminino & 83 & 37,2 & 17 & 45,9 & 113 & 50,9 \\
\hline Masculino & 140 & 62,8 & 20 & 54,1 & 109 & 49,1 \\
\hline Total & 223 & 100,0 & 37 & 100,0 & 222 & 100,0 \\
\hline
\end{tabular}

Fonte: Maciel Filho, 2007.

Os médicos que concluíram um ano e aqueles que renovaram eram, em sua maioria, do sexo masculino (62,8\% e 54,1\%, respectivamente, 
como mostra a Tabela 19). Já o maior percentual de desistências e desligamentos foi registrado entre as mulheres.

Foram os profissionais entre 30 e 40 anos que majoritariamente concluíram um ano de participação no Pits, mesma faixa etária da maioria dos desistentes ou desligados (Tabela 20). No entanto, foram os médicos mais velhos, com mais de 40 anos, que optaram por continuar no Programa por pelo menos mais um ano.

Tabela 20 - Distribuição dos médicos lotados no Pits, por situação no Programa e faixa etária - 2001-2003

\begin{tabular}{lrrrrrr}
\hline \multirow{2}{*}{ Faixa etária } & \multicolumn{7}{c}{ Situação no Pits } \\
\cline { 2 - 8 } & \multicolumn{1}{c}{$\begin{array}{r}\text { Concluíram 1 ano } \\
\text { de participação }\end{array}$} & $\begin{array}{r}\text { Renovaram a } \\
\text { participação por } \\
\text { mais 1 ano }\end{array}$ & $\begin{array}{r}\text { Desistiram ou } \\
\text { foram desligados }\end{array}$ \\
\cline { 2 - 8 } & $\mathrm{n}^{\circ}$ & $\%$ & $\mathrm{n}^{\circ}$ & $\%$ & $\mathrm{n}^{\circ}$ & $\%$ \\
\hline Menos de 30 anos & 44 & 19,7 & 3 & 8,1 & 39 & 17,6 \\
\hline Entre 30 e 40 anos & 67 & 30,1 & 12 & 32,4 & 85 & 38,3 \\
\hline Entre 41 e 50 anos & 52 & 23,3 & 16 & 43,3 & 52 & 23,4 \\
\hline Mais de 50 anos & 60 & 26,9 & 6 & 16,2 & 46 & 20,7 \\
\hline Total & 223 & 100,0 & 37 & 100,0 & 222 & 100,0 \\
\hline
\end{tabular}

Fonte: Maciel Filho, 2007.

Com relação ao estado civil, enquanto mais da metade dos médicos que concluíram sua participação no Pits $(53,4 \%)$ e dos que renovaram $(59,5 \%)$ eram casados, a maioria dos médicos desistentes ou desligados é de solteiros e descasados ( separados, divorciados e viúvos), totalizando 51,9\% (Tabela 21). Os três grupos, no entanto, em geral, possuíam dependentes, ainda que o percentual de desistentes e desligados com dependentes seja cerca de 10 pontos percentuais menor do que o dos dois outros grupos (Tabela 22).

A maioria dos médicos que chegaram a participar do Pits e que responderam ao questionário do estudo, não levou familiares, cônjuge ou companheiro(a) para os municípios de atuação (Tabela 23), porque não tinham (25,3\%), por não considerarem economicamente viável (24\%), por não terem desejado levá-los (17,7\%), ou ainda porque esses familiares não quiseram ir (8,9\%). 
Tabela 21 - Distribuição dos médicos lotados no Pits, por situação no Programa e estado civil - 2001-2003

\begin{tabular}{lrrrrrr}
\hline & \multicolumn{7}{c}{$\begin{array}{c}\text { Situação no Pits } \\
\text { Estado civil }\end{array}$} & $\begin{array}{r}\text { Concluíram 1 ano } \\
\text { de participação }\end{array}$ & $\begin{array}{r}\text { Renovaram a participação } \\
\text { por mais 1 ano }\end{array}$ & $\begin{array}{r}\text { Desistiram ou } \\
\text { foram desligados }\end{array}$ \\
\cline { 2 - 8 } & $n^{\circ}$ & $\%$ & $n^{\circ}$ & $\%$ & $n^{\circ}$ & $\%$ \\
\hline Solteiro & 83 & 37,2 & 9 & 24,3 & 77 & 34,7 \\
\hline Casado & 119 & 53,4 & 22 & 59,5 & 107 & 48,1 \\
\hline Separado & 6 & 2,7 & 1 & 2,7 & 17 & 7,7 \\
judicialmente & 14 & 6,3 & 5 & 13,5 & 20 & 9,0 \\
\hline Divorciado & 1 & 0,4 & 0 & 0,0 & 1 & 0,5 \\
\hline Viúvo & 223 & 100,0 & 37 & 100,0 & 222 & 100,0 \\
\hline Total & & & & & & \\
\hline
\end{tabular}

Fonte: Maciel Filho, 2007.

Tabela 22 - Distribuição dos médicos lotados no Pits, por situação no Programa e dependentes - 2001-2003

\begin{tabular}{lrrrrrr}
\hline & \multicolumn{7}{c}{ Situação no Pits } \\
\cline { 2 - 7 } Dependentes & $\begin{array}{r}\text { Concluíram 1 ano } \\
\text { de participação }\end{array}$ & $\begin{array}{r}\text { Renovaram a participação } \\
\text { por mais 1 ano }\end{array}$ & $\begin{array}{r}\text { Desistiram ou } \\
\text { foram desligados }\end{array}$ \\
\cline { 2 - 7 } & $\mathrm{n}^{\circ}$ & $\%$ & $\mathrm{n}^{\circ}$ & $\%$ & $\mathrm{n}^{\circ}$ & $\%$ \\
\hline Sim & 159 & 71,3 & 28 & 75,7 & 136 & 61,3 \\
\hline Não & 64 & 28,7 & 9 & 24,3 & 86 & 38,7 \\
\hline Total & 223 & 100,0 & 37 & 100,0 & 222 & 100,0 \\
\hline
\end{tabular}

Fonte: Maciel Filho, 2007.

Somente cerca de um quarto dos profissionais foi para os municípios com familiares, cônjuge ou companheiro(a), os quais, de modo geral, permaneceram até o término da participação do profissional no Programa.

A mesma tabela permite deduzir que o fato de levar familiares ou parceiros não funcionou como fator determinante na permanência dos médicos nos municípios. Isso porque, quando consideramos as três situações do profissional no Programa mostradas na tabela ('atua ou concluiu a participação'; 'desistiu depois de estar atuando'; 'desligado'), vemos que não há diferenças muito expressivas na proporção citada de $75 \%$ que não 
levaram acompanhantes contra $25 \%$ que levaram; além do que o percentual dos desistentes e dos desligados com acompanhantes é superior ao registrado entre os que ainda atuavam ou haviam concluído sua participação no Pits. Ou seja, os médicos que permaneceram no Programa não estavam, em sua maioria, acompanhados por familiares, cônjuges ou companheiros(as).

Tabela 23 - Distribuição dos médicos que responderam ao questionário, segundo situação no Pits e a ida de familiares, cônjuge ou companheiro(a) para o município de atuação

\begin{tabular}{|c|c|c|c|c|c|c|c|c|}
\hline \multirow{3}{*}{$\begin{array}{l}\text { Ida de familiares, cônjuge } \\
\text { ou companheiro(a) }\end{array}$} & \multicolumn{8}{|c|}{ Situação no Pits } \\
\hline & \multicolumn{2}{|c|}{$\begin{array}{r}\text { Atuam ou } \\
\text { concluíram sua } \\
\text { participação }\end{array}$} & \multicolumn{2}{|c|}{$\begin{array}{r}\text { Desistiram } \\
\text { depois de estar } \\
\text { atuando }\end{array}$} & \multicolumn{2}{|c|}{ Desligados } & \multicolumn{2}{|c|}{ Total } \\
\hline & $n^{0}$ & $\%$ & $n^{0}$ & $\%$ & $n^{0}$ & $\%$ & $n^{0}$ & $\%$ \\
\hline $\begin{array}{l}\text { Sim, e eles permaneceram } \\
\text { comigo até a minha volta }\end{array}$ & 8 & 19,0 & 7 & 26,9 & 3 & 27,2 & 18 & 22,8 \\
\hline $\begin{array}{l}\text { Sim, mas eles não } \\
\text { permaneceram comigo } \\
\text { até a minha volta }\end{array}$ & 1 & 2,4 & 0 & 0,0 & 0 & 0,0 & 1 & 1,3 \\
\hline $\begin{array}{l}\text { Não, porque não quis } \\
\text { levá-los comigo }\end{array}$ & 8 & 19,0 & 3 & 11,5 & 3 & 27,3 & 14 & 17,7 \\
\hline $\begin{array}{l}\text { Não, porque não } \\
\text { quiseram ir }\end{array}$ & 3 & 7,1 & 2 & 7,7 & 2 & 18,2 & 7 & 8,9 \\
\hline $\begin{array}{l}\text { Não, porque era inviável } \\
\text { economicamente }\end{array}$ & 10 & 23,8 & 8 & 30,8 & 1 & 9,1 & 19 & 24,0 \\
\hline $\begin{array}{l}\text { Não, porque eu não tinha } \\
\text { cônjuge e/ ou familiares }\end{array}$ & 12 & 28,7 & 6 & 23,1 & 2 & 18,2 & 20 & 25,3 \\
\hline Total & 42 & 100,0 & 26 & 100,0 & 11 & 100,0 & 79 & 100,0 \\
\hline
\end{tabular}

Fonte: Maciel Filho, 2007.

Contudo, a distância da família e dos amigos é tema de várias mensagens no fórum. São mensagens que revelam que o fato de 0 Programa ser destinado a populações carentes e sem assistência funcionou como uma compensação emocional para os profissionais, pela ausência de seus entes queridos.

Nós, pitianos, que abandonamos nossas famílias, nossos amigos, até mesmo nossos amores, podemos nos orgulhar de estarmos nessa batalha tentando um Brasil melhor, ajudando pessoas de lugares tão distantes a terem uma saúde mais digna. (Fórum Pits) 
Que você tenha um dia maravilhoso, mãe pitiana, que um dia deixou seu estado, sua casa, seus amigos e familiares, para ir em busca de um prazer que seria cuidar de pessoas carentes em município quase sem recurso algum, lutando pela qualidade de vida de seres humanos. Observamos que ainda, infelizmente, existe o analfabetismo nos municípios e, como todos sabem, isso atrapalha muito o nosso trabalho, desde o mais simples, queseria tomar um remédio certinho, até as informações que transmitimos mais complexas. Mesmo assim nunca desistimos de continuar o nosso trabalho e cada vez com mais garra. Só um desabafo: hoje é o dia das mães e também o dia de meu aniversário, no entanto estou aqui, no meu município de trabalho, me contentando com uma ligação telefônica de minhas três filhas e talvez de alguns amigos. Será que isso não representa nada??? (...) (Fórum Pits)

Em sua grande maioria, os médicos que chegaram a atuar no Pits não haviam feito nenhum curso de pós-graduação (Tabela 24). E foram exatamente profissionais sem pós-graduação que, majoritariamente, renovaram sua participação por mais um ano. O Programa chegou a contar com médicos com mestrado e doutorado, embora em percentuais quase inexpressivos. A maioria dos que possuíam mestrado desistiram ou foram desligados, mas o único médico com doutorado chegou a concluir um ano de participação no Programa.

Tabela 24 - Distribuição dos profissionais lotados no Pits, por situação e pós-graduação - 2001-2003

\begin{tabular}{lrrrrrr}
\hline \multirow{2}{*}{ Pós-graduação } & \multicolumn{7}{c}{\begin{tabular}{c} 
Situação no Pits \\
\cline { 2 - 8 }
\end{tabular}} & $\begin{array}{r}\text { Concluíram 1 ano } \\
\text { de participação }\end{array}$ & $\begin{array}{r}\text { Renovaram a participação } \\
\text { por mais 1 ano }\end{array}$ & $\begin{array}{r}\text { Desistiram ou } \\
\text { foram desl igados }\end{array}$ \\
\cline { 2 - 8 } & $n^{\circ}$ & $\%$ & $n^{\circ}$ & $\%$ & $n^{\circ}$ & $\%$ \\
\hline Sem pós-graduação & 137 & 61,5 & 31 & 83,8 & 132 & 59,5 \\
\hline Especialização & 79 & 35,4 & 6 & 16,2 & 80 & 36,0 \\
\hline Mestrado & 6 & 2,7 & 0 & 0,0 & 10 & 4,5 \\
\hline Doutorado & 1 & 0,4 & 0 & 0,0 & 0 & 0,0 \\
\hline Total & 223 & 100,0 & 37 & 100,0 & 222 & 100,0 \\
\hline
\end{tabular}

Fonte: Maciel Filho, 2007.

Mais uma vez, os dados convergem com o perfil dos médicos do PSF, onde apenas 37,2\% fizeram residência médica; 39,5\% possuíam especialização; e somente 23,6\% tinham título de especialista (Machado, 2000). 0 mesmo estudo mostra que ainda eram minoria os médicos que começavam a especializar-se em saúde da família, totalizando 3,7\% dos 
que trabalhavam no PSF no Brasil. A quase totalidade dos médicos $(96,4 \%)$ declarou necessidade de aprimoramento profissional.

O fato de o Pits proporcionar um curso de Especialização em Saúde da Família aos profissionais lotados funcionou como importante atrativo para que os médicos sem pós-graduação se interessassem em atuar no Programa. Isso é confirmado pelas respostas dos médicos ao questionário, no qual o curso de especialização aparece como o segundo fator considerado mais satisfatório no Programa, com 14\% de preferência, como mostra a Tabela 25. Em primeiro lugar, aparece ‘a atuação profissional junto às comunidades carentes' ( $15,8 \%$ ), que só não é citada como o fator mais satisfatório pelos médicos desistentes, para os quais é 'o curso de especialização' que fica em primeiro lugar. Em terceiro, quarto e quinto lugares, foram citados, pelo conjunto de profissionais, respectivamente, 'a remuneração' (13,5\%), 'a convivência e relacionamento com os demais profissionais do Programa' (11,3\%) e 'o funcionamento nos moldes do Programa de Saúde da Família' (10,7\%).

No entanto, para os que ainda atuavam ou já haviam concluído sua participação no Programa e também para os desligados, 'a remuneração' aparece como o segundo fator considerado mais satisfatório, passando à frente do 'curso de especialização' e da 'convivência e relacionamento com os demais profissionais do Programa', empatados em terceiro lugar. As respostas desses dois grupos de profissionais só não foram coincidentes na escolha do fator seguinte (quarto lugar): 'o funcionamento nos moldes do Programa de Saúde da Família' foi a preferência dos que ainda atuavam ou já haviam concluído sua participação e 'a experiência de conhecer outras áreas do país' foi a escolha dos desligados.

Para os desistentes 'a remuneração' só é citada em terceiro lugar ao contrário dos dois outros grupos que, como vimos, a consideraram como o segundo fator mais satisfatório - seguindo-se 'o funcionamento nos moldes do Programa de Saúde da Família', em quarto lugar.

0 fato de a maioria dos médicos que responderam ao questionário ter referido 'a atuação profissional junto às comunidades carentes' como o fator mais satisfatório da participação pode ser exemplificado com algumas mensagens disponíveis no fórum virtual do Programa.

Sempre acreditei na bondade do homem. No Brasil, passamos por um processo de amadurecimento de nossos ideais. (...) Que o povo de nossa nação possa cada vez mais ganhar e não perder as oportunidades que 
surgem. Portanto, ao tratarmos da saúde de nossas cidades, possamos desempenhar ações responsáveis e cada vez mais pensadas, a fim de que possamos construir o Bom Brasil - o Brasil da alegria, da saúde para todos, da esperança, da responsabilidade - o Brasil dos filhos de nossa Nação e, finalmente, irmãos e verdadeiros companheiros. (Fórum Pits)

Tabela 25 - Distribuição dos médicos que responderam ao questionário, segundo situação no Pits e o que consideraram satisfatório no Programa

\begin{tabular}{|c|c|c|c|c|c|c|c|c|}
\hline \multirow{3}{*}{ Fatores satisfatórios* } & \multicolumn{8}{|c|}{ Situação no Pits } \\
\hline & \multicolumn{2}{|c|}{$\begin{array}{r}\text { Atuam ou } \\
\text { concluíram sua } \\
\text { participação }\end{array}$} & \multicolumn{2}{|c|}{$\begin{array}{r}\text { Desistiram } \\
\text { depois de } \\
\text { estar atuando }\end{array}$} & \multicolumn{2}{|c|}{ Desligados } & \multicolumn{2}{|c|}{ Total } \\
\hline & $n^{0}$ & $\%$ & $n^{0}$ & $\%$ & $n^{\circ}$ & $\%$ & $n^{0}$ & $\%$ \\
\hline $\begin{array}{l}\text { A oportunidade de ingressar } \\
\text { no mercado de trabalho }\end{array}$ & 5 & 2,5 & 1 & 0,9 & 2 & 4,0 & 8 & 2,2 \\
\hline A remuneração & 25 & 12,3 & 16 & 14,4 & 8 & 16,0 & 49 & 13,5 \\
\hline O curso de especial ização & 24 & 11,8 & 20 & 18,1 & 7 & 14,0 & 51 & 14,0 \\
\hline A tutoria & 7 & 3,4 & 2 & 1,8 & 1 & 2,0 & 10 & 2,7 \\
\hline A moradia & 7 & 3,4 & 2 & 1,8 & 1 & 2,0 & 10 & 2,7 \\
\hline O transporte & 4 & 2,0 & 1 & 0,9 & 1 & 2,0 & 6 & 1,6 \\
\hline As condições de trabalho & 5 & 2,5 & 1 & 0,9 & 1 & 2,0 & 7 & 1,9 \\
\hline 0 acesso à internet & 13 & 6,4 & 7 & 6,3 & 2 & 4,0 & 22 & 6,0 \\
\hline $\begin{array}{l}\text { A coordenação do Ministério } \\
\text { da Saúde }\end{array}$ & 2 & 1,0 & 5 & 4,5 & 1 & 2,0 & 8 & 2,2 \\
\hline A coordenação estadual & 7 & 3,4 & 5 & 4,5 & 0 & 0,0 & 12 & 3,3 \\
\hline $\begin{array}{l}\text { A atuação da Secretaria } \\
\text { Municipal de Saúde }\end{array}$ & 7 & 3,4 & 2 & 1,8 & 0 & 0,0 & 9 & 2,5 \\
\hline O funcionamento nos moldes do PSF & 23 & 11,3 & 13 & 11,7 & 3 & 6,0 & 39 & 10,7 \\
\hline $\begin{array}{l}\text { A experiência de conhecer outras } \\
\text { áreas do país }\end{array}$ & 20 & 9,9 & 9 & 8,1 & 6 & 12,0 & 35 & 9,6 \\
\hline $\begin{array}{l}\text { A atuação profissional junto às } \\
\text { comunidades carentes }\end{array}$ & 30 & 14,9 & 17 & 15,3 & 10 & 20,0 & 57 & 15,8 \\
\hline $\begin{array}{l}\text { A convivência e relacionamento com } \\
\text { os demais profissionais do Programa }\end{array}$ & 24 & 11,8 & 10 & 9,0 & 7 & 14,0 & 41 & 11,3 \\
\hline Total & 203 & 100,0 & 111 & 100,0 & 50 & 100,0 & 364 & 100,0 \\
\hline
\end{tabular}

* Permitido marcar mais de uma opção.

Fonte: Maciel Filho, 2007. 
Referido como o segundo fator mais satisfatório, o curso de especialização também é destacado no fórum, onde se enfatizam os conhecimentos adquiridos e as pesquisas realizadas para as monografias de conclusão do curso.

Às vezes ficamos angustiadas pelo fato de o Pits encerrar, e sentimos uma sensação de não termos realizado tudo, mas não éverdade, fizemos muito, é verdade que houve alguns profissionais que vieram das suas terras para fazer turismo eficar no oba-oba (...) a maioria desenvolveu um bom trabalho nas suas comunidades, aproveitou a oportunidade de fazer especialização em Saúde da Família e desenvolveu boas pesquisas científicas, a exemplo, a minha pesquisa sobre os fatores que influenciam o desmame precoce na área de abrangência (...) , como também vi na relação dos classificados 0 nome de vários outros profissionais que fazem parte do Pits. Portanto, acho que o Pitsainda vai fazer parte da história da saúde do Brasil. E salve a nossa pátria!!! (Fórum Pits)

A referência à 'convivência e ao relacionamento com os demais profissionais do Programa', que, como vimos, foi um dos fatores considerados como mais satisfatórios pelos participantes, também está presente nas mensagens do fórum, onde aparece como elemento relevante e de estímulo à atuação dos profissionais, por meio da troca de experiências e do enriquecimento mútuo.

O programa de interiorização dos trabalhadores da saúde já começa a deixar saudades, muitos pediram transferências e outros desistência. A filosofia do programa proporcionou não só uma saúde preventiva de qualidade, como também uma integração nacional. Vocêsjá me conhecem, sou nordestina do estado do Maranhão eno munićpio que estou passaram: cearenses, paulistas, cariocas, paranaenses, mineiros e gente boa do Distrito Federal. 0 Pits propiciou aqui mudanças principalmente de atitude, esta em decorrência da consciência de profissionais de estados e regiões mais evoluídos politicamente, ondeas pessoas lutam pel os seus direitos eacreditam na justiça. Gente politizada que defende aquilo que acredita. Esse jeito de ser trouxe mudanças sociais significativas para o meu Estado. Estado onde o poder político e a politicagem imperam, assim como em outros lugares deste país, impedindo o cidadão de participar, intervir e manifestar sua opinião quanto ao descaso e à irresponsabilidade de alguns políticos que contaminam tudo o que se pretenda implantar de positivo para essa transformação social. O Pits deu certo. É por isso que vai acabar. Como tudo de bom nesse Brasil. (Fórum Pits)

Outro fator apontado como um dos mais satisfatórios e que também está presente nas mensagens do fórum é o funcionamento do Pits nos moldes do PSF, o que, para muitos profissionais, representou uma oportunidade de aprendizado e de abertura de campo de trabal ho. Duas 
mensagens ilustram bem esses aspectos. A primeira é uma mensagem conjunta de três médicas que já haviam concluído sua participação no Programa e relatavam para seus colegas os desdobramentos profissionais daí advindos; a segunda é de um médico que destaca as potencialidades do PSF como mercado de trabalho.

Aproveitamos esse momento para agradecer ao Nordeste (coordenações estaduais e municipais de atenção básica, colegas de equipes de PSF e, principalmente, 'nossas' comunidades) pelo aprendizado acumulado nos 30 meses departici pação no Programa. Foi aí queaprendemos evivenciamos o saúde da família em toda a sua dimensão teórica e prática. Hoje, com dificuldades, tentamos trazer esta experiência para nosso dia-a-dia no sul do país. Muito trabalho pela frente...!!!!!! (Fórum Pits)

Só no PSF já há mais de 20 mil equipes no Brasil, das quais, quem sabe, umas 5 mil já têm qualidade de razoável a ótima. A SBMFC [Sociedade Brasileira de Medicina de Família e Comunidade], o Ministério e muitas Secretarias de Saúde, além de milhares de profissionais, estão lutando para que as demais cerca de 15 mil equipes também alcancem qualidade. Se pensarmos só nas cerca de 5 mil equipes do PSF quejá atingiram qualidade, isso já é mais do que temos hoje, no Brasil, de médicos especialistas e qualificados verdadeiramente para ocupar esse espaço. Mas há também outros mercados de trabalho, fora do PSF - e alguns de boa qualidade. 0 que quero dizer com tudo isso?

a) Que, ao contrário de antigamente, não é mais raro um mercado de trabalho decente para quem se dedica à Atenção Primária em Saúde. Mesmo que a maior parte dos locais ainda seja muito ruim.

b) Que nesta Lista de Discussão énatural que se fale mais do que ainda é mais freqüente - Unidades do PSF sem qualidade e prefeituras que desconhecem nossa especialidade, não querem ou não sabem como qualificar o PSF. Mas há muitos lugares que não são assim e são pouco citados aqui nesta Lista.

c) Que o PSF não é o único mercado de trabalho em APS, e há locais bem melhores que a 'média' dos PSF.

d) Que há mais vagas de trabalho em APS do que médicos já bem qualificados para ocupá-las. Mas há um esforço do MS, da SBMFC, de universidades e outros para qualificar cada vez mais profissionais.

e) Que, nos locais (PSF e não) em que já se conquistou qualidade, é grande a satisfação profissional e pessoal dos médicos e das equipes como um todo, pelo trabalho que realizam.

f) Que 'nem tudo está perdido'. E minha previsão é quea tendência é de melhora, pois há muita gente batalhando por isso.

g) Que eu sou um otimista (...) (Fórum Pits) 
Até mesmo ex-participantes do Pits entraram no debate, explorando as dificuldades de inserção no mercado de trabalho proporcionado pelo PSF e de formação de profissionais para essa estratégia de atenção à saúde, e apresentando algumas sugestões:

Temos acompanhado a troca demensagens, (...) com relação à formação médica em APS. Gostaríamos de contribuir (...) como ex-integrantes do Pits desde o início de sua implantação em 2001. (...)

1) Há deficiência de mão-de-obra especializada no mercado. Para este momento, concordamos que transitório, algo tem que ser feito. Fora programas de residência, existem os cursos de especialização, oferecidos por instituições reconhecidas pelo MEC e MS. Não estamos vendo reconhecimento por este tipo de curso! Na prática estamos sendo nivelados àqueles profissionais sem formação na área, sequer com curso introdutório em PSF!

2) Sem entrar no mérito político de reinvenção ou não da roda, quando - MS 'pensa' na possibilidade de formação em áreas estratégicas através de bolsas, não estarão repetindo o Pits com outro nome? Sairão os profissionais desta formação com a incômoda sensação de tempo perdido? E a 'mão-de-obra' que foi qualificada pelo Pits, por que não ser aproveitada nestes futuros cursos de formação? A educação continuada (anteriormente programada para os 'pitiáticos') levaria também à formação de instrutores ou facilitadores para o ensino da especialidade. Tempo e dinheiro economizados. Fomos 'pagas' para fazer parte da dita mão-de-obra especializada!!!!!

3) Unificação da grade curricular da residência eadequação dos cursos de especialização às exigências da SBMFC.

(...)

5) Não devemos esquecer da diferença regional. Lá no NE, onde estivemos, as comunidades no interior só têm o PSF para recorrer, levando talvez a uma melhor compreensão (única opção?) da Atenção Primária pela sociedade. Será que nossas discussões não deveriam enfocar uma melhor definição e divulgação do modelo de atenção à população? (...) (Fórum Pits)

Mais da metade dos médicos que responderam ao questionário consideram que a experiência de ter participado do Pits foi positiva tanto em termos profissionais quanto para suas vidas pessoais (Tabela 26). Mas os que foram desligados do Programa pela coordenação nacional fazem uma avaliação diferente, dividindo-se, de modo geral, entre os que consideram a experiência negativa nos dois sentidos (profissional e pessoal) - que totalizam $27,3 \%$ - e os que admitem que a experiência foi positiva profissionalmente, mas negativa para suas vidas pessoais (outros $27,2 \%$ ). 
Tabela 26 - Distribuição dos médicos que responderam ao questionário, segundo situação no Pits e avaliação que fazem da experiência de ter participado do Programa

\begin{tabular}{|c|c|c|c|c|c|c|c|c|}
\hline \multirow{3}{*}{$\begin{array}{l}\text { Avaliação da experiência de } \\
\text { ter participado do Pits }\end{array}$} & \multicolumn{8}{|c|}{ Situação no Pits } \\
\hline & \multicolumn{2}{|c|}{$\begin{array}{r}\text { Atuam ou } \\
\text { concluíram sua } \\
\text { participação }\end{array}$} & \multicolumn{2}{|c|}{$\begin{array}{r}\text { Desistiram } \\
\text { depois de estar } \\
\text { atuando }\end{array}$} & \multicolumn{2}{|c|}{ Desligados } & \multicolumn{2}{|c|}{ Total } \\
\hline & $n^{\circ}$ & $\%$ & $n^{0}$ & $\%$ & $n^{0}$ & $\%$ & $\mathrm{n}^{0}$ & $\%$ \\
\hline $\begin{array}{l}\text { Foi positiva em termos } \\
\text { profissionais, mas negativa } \\
\text { para minha vida pessoal }\end{array}$ & 4 & 9,5 & 6 & 23,1 & 3 & 27,2 & 13 & 16,4 \\
\hline $\begin{array}{l}\text { Foi negativa em termos } \\
\text { profissionais, mas positiva } \\
\text { para minha vida pessoal }\end{array}$ & 6 & 14,3 & 1 & 3,8 & 2 & 18,2 & 9 & 11,4 \\
\hline $\begin{array}{l}\text { Foi positiva tanto em termos } \\
\text { profissionais quanto para } \\
\text { minha vida pessoal }\end{array}$ & 27 & 64,3 & 15 & 57,7 & 2 & 18,2 & 44 & 55,7 \\
\hline $\begin{array}{l}\text { Foi negativa tanto em termos } \\
\text { profissionais quanto para } \\
\text { minha vida pessoal }\end{array}$ & 5 & 11,9 & 4 & 15,4 & 3 & 27,3 & 12 & 15,2 \\
\hline Não sei avaliar & 0 & 0,0 & 0 & 0,0 & 1 & 9,1 & 1 & 1,3 \\
\hline Total & 42 & 100,0 & 26 & 100,0 & 11 & 100,0 & 79 & 100,0 \\
\hline
\end{tabular}

Fonte: Maciel Filho, 2007.

Essa boa avaliação que os médicos, de modo geral, fizeram da experiência de ter participado do Pits, é reforçada quando se analisa o que esses profissionais responderam, no questionário, ao serem indagados sobre o que consideravam mais adequado para os rumos futuros do Programa (Tabela 27). Mais da metade deles optaram pela manutenção do Programa no formato em que estava, mas com aperfeiçoamentos constantes (57\%). Outros $26,6 \%$ entenderam que o Pits deveria ser transformado em serviço civil obrigatório, destinado a recém-formados e com remuneração. M as 16,4\% defenderam sua extinção. Aliás, a opção pela extinção do Programa obteve expressivos percentuais entre os médicos que foram desligados ( $27,3 \%$ ) e entre os que ainda atuavam ou já haviam concluído sua participação (19\%).

Os rumos do Programa foram uma preocupação constante para os profissionais participantes, seja em uma perspectiva de curto prazo, em que o que prevalece é o próprio interesse pessoal, seja em uma perspectiva mais politizada e de cidadania. 
Tabela 27 - Distribuição dos médicos que responderam ao questionário, segundo situação no Pits e o que consideram mais adequado para os rumos futuros do Programa

\begin{tabular}{|c|c|c|c|c|c|c|c|c|}
\hline \multirow{3}{*}{$\begin{array}{l}\text { Opção que considera mais } \\
\text { adequada para os rumos } \\
\text { futuros do Pits }\end{array}$} & \multicolumn{8}{|c|}{ Situação no Pits } \\
\hline & \multicolumn{2}{|c|}{$\begin{array}{r}\text { Atuam ou } \\
\text { concluíram sua } \\
\text { participação }\end{array}$} & \multicolumn{2}{|c|}{$\begin{array}{r}\text { Desistiram } \\
\text { depois de } \\
\text { estar atuando }\end{array}$} & \multicolumn{2}{|c|}{ Desligados } & \multicolumn{2}{|c|}{ Total } \\
\hline & $n^{\circ}$ & $\%$ & $n^{0}$ & $\%$ & $n^{0}$ & $\%$ & $n^{0}$ & $\%$ \\
\hline $\begin{array}{l}\text { Sua manutenção no formato } \\
\text { atual, com aperfeiçoamentos } \\
\text { constantes }\end{array}$ & 23 & 54,8 & 16 & 61,5 & 6 & 54,5 & 45 & 57,0 \\
\hline $\begin{array}{l}\text { Sua transformação em serviço } \\
\text { civil obrigatório, destinado a } \\
\text { recém-formados, com } \\
\text { remuneração }\end{array}$ & 11 & 26,2 & 8 & 30,8 & 2 & 18,2 & 21 & 26,6 \\
\hline Sua extinção & 8 & 19,0 & 2 & 7,7 & 3 & 27,3 & 13 & 16,4 \\
\hline Total & 42 & 100,0 & 26 & 100,0 & 11 & 100,0 & 79 & 100,0 \\
\hline
\end{tabular}

Fonte: Maciel Filho, 2007.

A perspectiva mais politizada aparece em diversas mensagens trocadas no fórum. São depoimentos que enfatizam ações e políticas para o aperfeiçoamento do Programa e do próprio SUS, exploram as potencialidades das instâncias de controle social, estimulando a participação dos profissionais e da população, e propõem estratégias para uma política de fixação de profissionais.

Foi realizada a 6ạ Conferência Estadual de Saúde do Maranhão, onde foram escolhidos, dentreoutros, 2 ( dois) delegados ( pitianos), representando os trabalhadores de saúde deste estado e que certamente defenderão propostas pertinentes à atenção básica deste país, na qual nosso programa está inserido, como também a efetivação de algumas metas traçadas pela política de saúde nacional, como:

- a câmara de regulação do trabalho em saúde;

- o programa nacional de desprecarização do trabalho em saúde;

- mesa permanente de negociação de gestão com trabalhadores da área, visando assegurar os direitos trabalhistas do profissional de saúde;

- cumprimento e respeito aos prinćpios ediretrizes do SUS, de forma a garantir a participação da sociedade no processo de consolidação democrática.

Aos profissionais que acreditam nesse processo e no Sistema Único de Saúde, junte-se a nós e participe das discussões deste Fórum, com propostas 
e soluções, para que juntos encontremos respostas equilibradas e sensatas a dilemas que há muito tempo entravam o desenvolvimento da saúde como um todo neste país. Participe, dê sua contribuição para revertermos este quadro tão característico da nossa saúde. A 12a Conferência Nacional de Saúde está próxima etodo cidadão pode participar democraticamente deste evento, vamos criar uma corrente positiva para quea saúde do Brasil possa mudar para melhor. (Fórum Pits)

Acontece de 7 a 11 de dezembro, em Brasília, a 12a Conferência Nacional de Saúde, com o tema central 'Saúde: um direito de todos e um dever do Estado: a saúdequetemos, o SUS que queremos', ondeilustres palestrantes abordarão temas como o desenvolvimento do Sistema Único de Saúde: avanços, desafios e reafirmação dos seus princípios e diretrizes. Leiam 0 manual publicado pelo Ministério e o Conselho Nacional de Saúde sobrea reestruturação dos programas e projetos federais 'especiais' (item 7), dentre estes o Pits. (Fórum Pits)

\section{Por fim, os médicos que participaram do Pits apontam, ainda no fórum, os resultados positivos do Programa:}

Desdeagosto de2001, atuo no município de[nome do município], situado a leste do estado do Maranhão, distante $460 \mathrm{~km}$ da capital, sendo o acesso por estradas muito difíceis. A população (4.705) sobrevive da agricultura de subsistência edos empregos gerados pelo funcionalismo público. No início do ano de2003, passamos a desenvolver um projeto ( ...) ondea participação social é a alavanca mestra. Conseguimos, utilizando a metodologia lúdica problematizadora e priorização de problemas, algumas soluções como: coleta do lixo, esclarecimento da população quanto à (...) conservação do meio ambientee encaminhar à Câmara projetos de lei para votação edeliberação. Gostaria também de convidá-los para juntos escrevermos um livro, onde cada um encaminhasse uma página pitoresca ou de alguma situação que presenciou para ser editado, com a verba sendo revertida para ações sociais. (Fórum Pits)

O Pits serviu como um bonito início ao Programa Saúde da Família... muitos de nós aprendemos a fazer PSF através desta estratégia. Aqui no Ceará, assessorados pela Universidade Federal, tivemos a possibilidade de desenvolver diversos trabalhos eestudos nas diversas comunidades, o quenos possibilitou trabalhar melhor a Atenção Primária. Nossa escolha, desde 0 início, foi desenvolver os vários projetos em conjunto: Universidade Federal, secretarias estadual e municipal de Saúde e profissionais de saúde. Mais tarde, trabalharíamosjunto aosnossos Clientes (população adscrita), através do Conselho de Saúde. Ao chegarmos em [nome do município] (Ce), há cerca de dois anos e meio atrás, encontramos uma situação devastadora, num município de pior taxa de mortalidade infantil do Ceará e vários problemas de saúdea resolver. Obtivemos, com o nosso trabalho conjunto, 0 reconhecimento de sermos um dos municípios da região (...) que mais se desenvolveu na área da saúde, nos últimos meses (...). (Fórum Pits) 
O Programa de Interiorização dos Trabalhadores da Saúde-Pits não é apenas uma estratégia que deu certo, é também uma grande família que para realizar seu trabalho, seja ele assistencial ou educativo, muitas vezes vai de encontro à politicagem sórdida eà falta de compromisso dos gestores municipais. 0 fato de os profissionais não estarem totalmente atrelados aos recursos locais favorece a credibilidade da comunidade e 0 desenvolvimento de atividades de sensibilização social. 0 intercâmbio de profissionais de diversas regiões do país possibilita a troca de experiências, costumes, hábitos e crenças, despertando um sentimento de solidariedade entretodos. Acreditamos ter resgatado a dignidade de uma pequenina parte da nossa gente, acreditamos ter contribuído para a história da saúde pública deste maravilhoso BrasillIII. (Fórum Pits)

Priorizamos a qualidade dos cuidados com a saúde. Neste sentido, a Secretaria de Saúde Municipal contribuiu para a reforma do Centro de Saúde (...), de modo a melhorar a prestação de nossos serviços. Também intensificamos a vigilância na qualidade do atendimento aos vários tipos de clientela e faixas etárias, como as crianças, mulheres, idosos, pacientes crônicos, hipertensos, diabéticos, tuberculosos e doentes de hanseníase. Enfatizamos as medidas preventivas, como a prevenção do câncer de mama e do colo uterino. Estamos fazendo visitas domiciliares de rotina àqueles que não podem se movimentar ao centro de saúde. 0 prontuário familiar foi implementado. Foi dada preferência à caracterização dos diversos prontuários individuais de acordo com as peculiaridades de cada clientela. Por exemplo, temos prontuários específicos para o atendimento de idosos, crianças, adolescentes, mulheres, pacientes psiquiátricos, etc. Administramos cursos de capacitação aos diversos agentes de saúde. Também utilizamos, muitas vezes, o nosso tempo em reuniões de integração, confraternização, recidagem e planejamento deações. Em relação às várias estatísticas existentes, a cidade de [nome do município] melhorou bastante na questão saúde. Diminuímos consideravelmentea mortalidade infantil, a mortalidade geral; melhoramos os índi ces devacinação, além de outras conquistas. Atualmente, trabalhamos junto às comunidades, tentando compreender mais a fundo as várias necessidades da população, visando, assim a um desenvolvimento sustentável da atenção primária. (Fórum Pits)

Foi oferecido, através de monitoria oficial, curso adaptado aos futuros Conselheiros Locais de Saúde de nossa área de abrangência. Utilizou-se o Guia do Conselheiro e o Caderno de Atividades do Curso de Capacitação de Conselheiros Estaduais e Municipais de Saúde, do Ministério da Saúde, além de outros materiais pedagógicos. Está sendo uma experiência com ativa participação comunitária. Mais oficinas deverão ser feitas, visando à conscientização e à formação de Conselheiros responsáveis e atuantes. (Fórum Pits)

Estão sendo empossados, hoje, os mais novos consel heiros (locais) desaúde, representantes das áreas atendidas por nossa equipe de Pits/ PSF, em [nome do município]. Nesta ocasião festiva, serão fornecidos os certificados do curso decapacitação para conselheiros de saúde, fornecidos pela Secretaria Municipal 
deSaúde. Ficamos contentes determos mais um instrumento a nossa disposição, rumo a uma saúde mais eficientee democrática. (Fórum Pits)

No documento "Tópicos da política de desenvolvimento de recursos humanos para o Sistema Único de Saúde", o Ministério da Saúde, ao se referir à avaliação efetuada sobre o Pits, afirma que:

Um dos principais resultados positivos encontrados na avaliação diz respeito à constatação por parte dos pesquisadores de que na maioria dos locais surgem indícios de que os profissionais interiorizados começam a vivenciar o cotidiano daquele município, o que pode ser considerado como pré-requisito básico para que esses médicos e enfermeiros passem a se sentir como parte daquela comunidade, podendo ocasionar posterior fixação. (Brasil, 2002h: 19)

No mesmo documento, o Ministério aponta aspectos positivos verificados ao longo da vigência do Pits, tais como:

- grande receptividade ao programa por parte da comunidade;

- melhoria da qualidade de assistência à saúde;

- contribuição na organização dos serviços locais de saúde;

- contribuição na reativação dos Conselhos Municipais de Saúde;

- melhora na cobertura vacinal, puericultura, assistência pré-natal, prevenção do câncer ginecológico e no controle da hipertensão arterial, diabetes, hanseníase e doenças sexualmente transmissíveis;

- melhoria dos indicadores de saúde e dos sistemas de informação (Brasil, 2002h: 18)

\section{Atuação da Coordenação Nacional}

Foi na então Secretaria de Assistência à Saúde (SAS), que se iniciou a discussão, no âmbito do Ministério, para a formulação do Pits. Com a criação, logo a seguir, da Secretaria de Políticas de Saúde (SPS), o debate se transferiu para lá, onde efetivamente o Pits foi formulado. A idéia de criar o Programa, segundo o então secretário de Políticas de Saúde, entrevistado para o estudo da Rede Observatório de Recursos Humanos em Saúde, surgiu como reação a uma das questões que se colocavam 
como críticas para a expansão do PSF: a dificuldade de interiorizar médicos. A queixa, segundo o entrevistado, partia dos secretários municipais de saúde e também dos prefeitos.

Foram feitos alguns estudos e recuperados outros já existentes, de forma a obter subsídios técnicos e jurídicos que orientassem a opção por uma determinada alternativa. 0 passo seguinte foi gerar um ambiente favorável para uma parceria entre o governo federal (envolvendo o Ministério da Saúde, o M inistério da Educação e o Ministério da Ciência e Tecnologia), as entidades médicas, o Conass e o Conasems.

Foi criada uma coordenação nacional para a execução do Programa, ligada à área técnica de recursos humanos da própria Secretaria de Políticas de Saúde. Isso facilitou a condução de outras políticas paralelas de recursos humanos, como a política de mudanças curriculares.

A Portaria n. 227/GM, de fevereiro de 2001, estabeleceu as atribuições da coordenação nacional, cujo cumprimento foi cheio de percalços (Brasil, 2001b). Aqui serão destacados mais especificamente os aspectos que influenciaram, positiva e negativamente, a adesão dos médicos ao Programa, tomando-se como principais fontes para isso as mensagens disponíveis no Fórum do Pits, as entrevistas com os gestores e documentos técnicos. 0 objetivo é analisar a atuação da coordenação nacional no que se refere ao cumprimento de suas atribuições precípuas: o repasse de recursos e o provimento de meios para o processo de educação, pesquisa e supervisão permanentes.

Segundo o Relatório de Gestão do Ministério da Saúde, o Programa contou com "um sistema permanente de controle e avaliação", que teve como finalidade "(...) identificar os fatores favoráveis e desfavoráveis, para que se proceda às correções necessárias" (Brasil, 2002e: 60). Para proceder à avaliação, a coordenação nacional criou e capacitou uma equipe, composta por 12 técnicos, que fizeram reuniões nos estados com os tutores e coordenações estaduais do Programa e do curso de especialização. A mesma equipe realizou reuniões, nos municípios, com os gestores e representantes das comunidades, além de visitas às unidades básicas e às moradias dos profissionais, os quais responderam a um questionário de avaliação.

Nos quatro primeiros meses do Programa, foram visitados 56 municípios de 16 estados, o que representou $40,0 \%$ do total de cidades participantes. A amostra incluiu municípios que 
apresentam alta e baixa densidade populacional, diferente grau de dificuldade de acesso e de distância da capital, e número variável de equipes. Quando o programa completou nove meses, o restante dos municípios foi visitado. (Brasil, 2002e: 60)

Por meio da verificação in loco e de entrevistas, os técnicos avaliaram o desempenho da coordenação estadual e dos tutores, a contrapartida dos gestores e o desenvolvimento do Programa.

Iniciando pela tutoria e supervisão, vê-se que a avaliação promovida pelo Ministério revelou que $43,8 \%$ dos médicos participantes do Pits a qualificaram como 'boa'; mas outros $43,8 \%$ a consideravam 'insuficiente'; e mais $12,5 \%$ como 'regular', o que totaliza quase $57 \%$ de médicos insatisfeitos (Brasil, 2002e). Esses dados são compatíveis com as respostas dos médicos ao questionário aplicado pelo estudo da Rede Observatório de Recursos Humanos em Saúde, quando indagados acerca dos fatores que consideraram satisfatórios no Programa (apresentados na Tabela 25). Na referida tabela, observa-se que a tutoria contou com um percentual de apenas 2,7\% de citação como fator satisfatório.

Os tutores foram selecionados pelas secretarias estaduais de Saúde e remunerados pelo Ministério, via Conselho Nacional de Desenvolvimento Científico eTecnológico (CNPq), por meio de uma bolsa no valor de $\mathrm{R} \$ 1.500,00$. A tutoria foi realizada com o uso da internet e visitas periódicas de acompanhamento, tendo como objetivo “( ...) atender às demandas dos profissionais referentes à capacitação e atuação prática no serviço de saúde" (Brasil, 2002e: 59).

Há mensagens no fórum do Pits que confirmam a insatisfação e até mesmo a inexistência de tutoria em algumas localidades:

\section{(...) os tutores não receberam das Secretarias Estaduais de Saúde condi ções para exercerem adequadamente suas funções ( ...) (Fórum Pits)}

(...) Que diferença entre o discurso e a prática. Basta analisar o que foi prometido e o que está sendo oferecido. Nem tutor médico existe aqui para [nomedo município]. Quem éo culpado por tanta bagunça? (Fórum Pits)

O ex-secretário de Políticas de Saúde admite que houve problemas com a tutoria: "(...) um problema operacional, a tutoria, mas foi pelo menos a primeira experiência de tutoria que se teve, quer dizer, havia o tutor, então algumas funcionaram, outras não funcionaram (...)" (Maciel Filho, 2007: 160). 
Já no que se refere ao curso de especialização, ainda segundo a avaliação promovida pelo Ministério da Saúde, $60 \%$ dos médicos 0 consideraram 'bom' (Brasil, 2002e). No entanto, o curso foi reputado como 'regular' por $22 \%$ e 'ruim' por $9 \%$, o que totaliza $31 \%$ de médicos insatisfeitos. Esse percentual é expressivo se considerarmos que o curso foi encomendado pelo Ministério especificamente para o Pits. Eé agravado quando se verifica que:

- somente para $52 \%$ dos profissionais, o conteúdo ministrado foi considerado 'bom' para o desempenho das demandas de atendimento do Pits ( $33 \%$ o avaliaram como 'regular' e 9\% como 'ruim');

- a metodologia do curso foi reportada como 'boa' por $50 \%$, 'regular' por 32\% e 'ruim' por 11\%;

- as atividades planejadas para o período de dispersão foram referidas como 'compatíveis' por $64 \%$ e 'incompatíveis' por $22 \%$ (somente $44 \%$ dos profissionais executavam 'totalmente' as atividades previstas para o período de dispersão, $26 \%$ realizavam 'parcialmente' e 17\% 'não executavam'). ${ }^{11}$

Um problema relevante enfrentado pela coordenação nacional para a oferta do curso de especialização é apontado pelo ex-secretário de Políticas de Saúde, que admite ter sido difícil administrar o deslocamento dos profissionais para freqüentarem o curso nas capitais.

0 que a gente sentiu de maior dificuldade nesses cursos de especialização foram os deslocamentos, quer dizer, havia deslocamentos dos municípios para as capitais, uma certa dificuldade das faculdades de interiorizarem o curso para os municípios, até porque os municípios eram de regiões diferentes, um problema operacional (...). (Maciel Filho, 2007: 161)

De qualquer forma, a coordenação nacional procurou superar essa dificuldade da melhor forma possível e estimular a formação e o interesse dos profissionais na área de saúde da família, como, por exemplo, patrocinando passagens aéreas para os que desejassem fazer a prova de especialista em medicina de família e comunidade, da SBM FC.

11 Dados adicionais sobre a avaliação do curso de especialização oferecido pelo Pits podem ser encontrados em Seixas e Stella (2002), que realizaram um estudo específico com este fim. 
No entanto, em alguns estados houve atrasos consideráveis no início do curso e mesmo nas atividades de educação continuada, ${ }^{12}$ conforme mensagens disponíveis no fórum do Pits. Houve demora também na emissão dos certificados de conclusão do curso de especialização, de participação no Pits e do Diploma de Serviços Prestados à Nação, o que foi tema de diversas mensagens no fórum, inclusive com dúvidas a respeito da própria titulação obtida com o curso:

Ontem, 28 de novembro, houve uma reunião (...) entre profissionais do Pits 1, 2 e 3, tutores ecoordenação estadual. (...) solicitamos à coordenadora estadual que se informasse sobrealgumas coisas que estão nos regulamentos do pits e que até então não foram cumpridas, tais como:

- Diploma de serviços prestados à nação;

- Certificado de participação no Pits ( 0 Pits 1 recebeu apenas referente ao $1^{\circ}$ ano);

- Certificado de participação no curso de acompanhamento para egressos do Pits 1 (realizado pela UFC no caso do Ceará); (...)

- Como fica a situação de nós médicos a respeito da possibilidade de ter direito a fazer prova detitulação pela Sociedade Brasileira de Medicina de Família e Comunidade???? Segundo o que sabemos, o CFM não reconhece nosso diploma de especialização e não sabemos se a AMB nos permitirá fazer a prova, já que nosso tempo de especialização e trabalho de campo não foram devidamente supervisionados. (...) (Fórum Pits)

(...) não consigo entender por que todo esse mistério em torno de resposta tão simples. Temos direito a estes certificados e também temos direito a uma resposta uma vez que é motivo de orgulho e conta pontos em nossos currículos (...) Aqui no Ceará está para sair um edital para concurso público e estes certificados são de suma importância (...). (Fórum Pits)

Vários profissionais ressaltaram a relevância que atribuem ao Diploma de Serviços Prestados à Nação e o orgulho em vir a recebê-lo.

Já tenho em minhas mãos o 1 - certificado, aquele assinado pelo Ministro Barjas Negri, e estou ansioso para receber os restantes. Deve ser tocante receber diploma de serviços prestados à nação, é o que está faltando no meu currículo. (...) (Fórum Pits)

(...) estou feliz elisonjeada em receber estes certificados. (Fórum Pits)

12 Para os profissionais que permaneceram por mais de um ano no Programa, o Ministério da Saúde ofereceu cursos de educação a distância, a partir de parceria com a Escola Nacional de Saúde Pública da Fundação Oswaldo Cruz (Ensp/Fiocruz). 
Sou do Pits I e só recebi o certificado de participação do primeiro ano. Quero saber quando receberemos os outros dois certificados e por onde anda o nosso certificado deserviços relevantes prestadosa nação. Um mérito e orgulho pessoal de cada um têlo e eu não abro mão. (Fórum Pits)

Algumas das dificuldades da tutoria, do curso de especialização e da educação continuada podem ser atribuídas aos problemas de conectividade com a internet, enfrentados em várias localidades. 0 M inistério da Saúde formou uma Comissão de Conectividade, composta por representantes do próprio Ministério e do CNPq, encarregada da aquisição e distribuição de equipamentos de informática para uso dos profissionais do Pits nos municípios, devendo ainda, “(...) viabilizar a instalação de linhas telefônicas para acesso a e-mail, web, biblioteca virtual, e 0 acesso a tutores e a cursos de especialização e a educação a distância" (Brasil, 2002e: 59). O processo de compra e distribuição dos equipamentos foi iniciado em outubro de 2001, “(...) tendo sido adquiridos 315 computadores completos. Até março de 2002, foram entregues 95,6\% dos equipamentos" (Brasil, 2002e: 59). As linhas telefônicas, não residenciais, foram instaladas nos postos de saúde ou na residência dos profissionais, com serviço de discagem direta gratuita (0800) específico para o Pits, com alcance estadual, para contato com as coordenações estaduais. As linhas também contavam com serviço discado para acesso à internet. Mas, das 2.490 linhas necessárias, só haviam sido instaladas 151, até agosto de 2002 (Brasil, 2002e, 2002f).

Os profissionais que não enfrentavam esse tipo de problema serviam, muitas vezes, no fórum do Pits, como porta-vozes dos demais, com os quais se comunicavam por telefone. Mesmo assim, os que dispunham dos meios de comunicação, também enfrentavam problemas:

Creio quea maioria dos profissionais de saúde vive em cidades onde não existe provedor para internet, nem serviços diferenciados (...); e para participarmos deste fórum, por exemplo, pagamos taxas de interurbano. (Fórum Pits)

Mas o processo de comunicação não foi dificultado apenas por fatores tecnológicos. A comunicação entre a coordenação nacional e os profissionais não se mostrou muito eficaz ao longo do desenvolvimento do Programa. Inicialmente, a criação do fórum foi muito elogiada pelos profissionais nas próprias mensagens ali postadas, criando uma expectativa de que a partir de então a comunicação com a coordenação nacional estaria facilitada: 
Olá, felicitações a todos os pitianos e coordenação federal do Pits, enfim, a todos que colaboraram para que este Fórum fosse criado. (...) acho que este novo espaço está nos dando a oportunidade de melhor aproximação também com a coordenação federal do programa eisto muito nos interessa, além de ampliarmos o nosso círculo de amizades com os colegas pitianos do Brasil inteiro. Parabéns pelo fórum e a todos os participantes. Ainda acho poucos integrantes, mas acredito que seja por conta da dificuldade técnica mesmo. Vamos aproveitar, esta será uma oportunidade ímpar!!! (Fórum Pits)

Contudo, muito rapidamente, o fórum se transformou em instrumento de comunicação usado eminentemente pelos profissionais, com pouca participação da coordenação nacional. Essa precária comunicação com a coordenação funcionou, por vezes, como um fator a mais de desgaste, chegando mesmo a agravar as críticas e o descrédito por parte de vários profissionais. O próprio fórum ilustra bem esse aspecto, com inúmeras mensagens de queixa acerca da falta de atenção e comunicação por parte da coordenação nacional. Eis alguns exemplos:

Aqui no Fórum nossas dúvidas têm sido respondidas pel os colegas e não pela coordenação federal (...). (Fórum Pits)

Creio que boa parte do pessoal que está atualmente no Ministério da Saúde antes queixava-se da falta de comunicação dos gestores anteriores. A história está se repetindo. Não nos informam nada (...). 0 interessante é que foi enfatizada a importância da comunicação durante o curso do Pits (...). (Fórum Pits)

Quando paro e penso, olho para o meu passado, tudo que deixei para trás, como muitos dos colegas, por acreditar em um Brasil melhor, vejo que somos fantoches nas mãos de políticos eque apesar detantos anos deestudo, procurando sempre fazer o melhor para o próximo, muitas vezes somos manipulados e enganados. (Fórum Pits)

Quando um dia, por qualquer razão, não estiveres ocupando um cargo, porque é assim que acontece, um dia da caça, outro do caçador, não se esqueça de todos esses e-mails encaminhados que permaneceram sem respostas. Venha conhecer o Norte, o Nordeste, anonimamente, venha viver o dia-a-dia de um profissional de saúde, venha ver como as verbas chegam à população. (...) Continuem nos ignorando, continuem não mandando respostas. (Fórum Pits)

Houve também problemas no cumprimento de garantias previstas no regulamento do Programa, quanto ao provimento de recursos básicos para o exercício das atividades dos profissionais e condições de trabalho. Esses problemas incluíram atrasos e até mesmo não recebimento do kit de assistência farmacêutica básica, do kit de equipamentos básicos e dos 
livros didáticos. Diversas mensagens no Fórum do Pits ilustram os problemas enfrentados pel os profissionais:

Gostaria de saber se ainda este ano [ novembro de 2003] receberemos o kit da farmácia básica (...) Estes kits nos ajudam muito, pois a prefeitura compra muito pouco (...).(Fórum Pits)

Espero que a verba seja viabilizada de forma que possamos realmente recebêla, pois a situação de nossos municípios é péssima quanto a isso. A farmácia básica é imprescindível para a implementação dos programas, pois é só o que temos de medicamentos para oferecer à população e aqui no Maranhão há muito tempo não recebemos. (Fórum Pits)

Sou do muniápio do [nome do município] e também gostaria de saber quando iremos receber nosso kit básico da farmácia, pois o mesmo faz muita falta, pela carência da população, distância da capital de $600 \mathrm{Km}$, estrada de chão (...). (Fórum Pits)

Aqui em [nome do muniápio], recebemos os kits $A$ e B há cerca de duas semanas atrás e eles vieram violados. É a segunda vez que isso acontece e faltam-nos medicações importantes para os programas de atenção básica, inclusive as sacolas de distribuição. (...) Mas realmentegostaria de saber se é só aqui que isso acontece... Aliás, já começo a sentir saudades dos kits de atenção à mulher epreservativos; notamos diferença no perfil de gestações. Aliás, também sinto falta dos kits do programa de prevenção de colo uterino... (...). (Fórum Pits)

O nosso kit também foi violado e 'filtrado'. Tudo que o violador achou bom ficou para ele. Já reclamei com quem de direito em Brasília (...) e nada aconteceu, continua o problema. (Fórum Pits)

Só respondo agora, pelo longo período sem comunicação pela internet no Pits. Quero aqui aproveitar para questionar. (...) o programa não vem cumprindo as propostas do início, tais como: kit com oftalmoscópio e outros materiais, inclusive livros (...). (Fórum Pits)

No segundo semestre de 2003, começaram a surgir comentários, no fórum do Pits, dando conta de que o Programa seria extinto ainda naquele ano. Isso gerou muitas dúvidas e angústias por parte dos profissionais, manifestadas no próprio fórum, onde indagavam à coordenação nacional sobre a veracidade dessas informações. A falta de respostas por parte da coordenação acirrou o desgaste entre as duas partes. Somente em novembro a coordenação nacional informou, por meio do fórum, que:

Após a realização do Seminário de Avaliação realizado em Brasília nos dias 01 e 02 de julho de 2003, iniciamos o processo de reformulação do Programa de Interiorização do Trabalho em Saúde - Pits, com o objetivo 
de integrá-lo às estruturas do SUS, particularmente à atenção básica, desencadeando a transição do Programa para os sistemas municipais de saúde e buscando assegurar a permanência das equipes nos municípios. $\mathrm{Na}$ certeza desua compreensão, peço a gentileza que aguardenovas informações mais precisas e concretas com relação ao referido Programa, pois ainda estamos em fase de negociação. (Fórum Pits)

\section{O informe não foi suficiente para aplacar a ansiedade dos profissionais que continuaram se manifestando a respeito no fórum:}

Olá, companheiros do Pits. (...) Vou aproveitar para fazer um desabafo e tirar um pouco dessa tristeza que teima em chegar devagarzinho, quando penso no futuro de nosso trabalho. Está ficando difícil dar respostas para meus amigos das comunidades onde trabalho, a respeito da continuidade do Pits. Estão acontecendo várias consultas, onde meus pacientes querem apenas saber se vamos continuar ou não. E eu procuro, da melhor forma, explicar que ainda está para ser definido. Depois de 2 anos e meio de luta, de resistência, de persistência, de construção de laços de confiança e de amizade, estamos sedimentando todas as nossas frentes de trabalho, e 0 melhor, com a ajuda da população. Agora que começamos a sentir e ver os frutos de nossa semeadura, vem a tristeza de pensar que tudo isso pode ficar pra trás. Que me desculpem as pessoas da coordenação nacional, mas até agora não entendi exatamente o que querem dizer com 'fazer parte efetivamente da estrutura do SUS', pois sempremeconsiderei uma 'fazedora' do SUS. Se isso significa depender da estrutura dos municípios em que estamos, para continuidade do projeto, não posso falar por todos, mas a realidade aqui é que não teremos como continuar. Sinto dizer que um dos fatores que manteve a permanência e o respeito pelo Pits foi o fato de estarmos ligados 'diretamente' ao MS, o que possi bilitou a implementação de várias ações, uma vez que de certa forma atuamos como 'fiscalizadores'. (...) espero de coração, assim como vários dos meus amigos-pacientes que aqui conheci, que o Pits não passe a ser mais um desses 'projetos-foguete', brilham muito quando iniciados, mas apagam-se, deixando um vazio para aqueles que participaram do espetáculo. Um grande abraço a todos. (...). (Fórum Pits)

É (...), aqui em [nome do município], a situação não é diferente... tem pacientes que começam a chorar, quando também não me fazem chorar. Tanto o secretário quanto o prefeito mostram as mais belas intenções de manter nossa equipe, mas sei que o município não tem condições, tudo devido à má administração do dinheiro público, diga-se de passagem. Estes últimos meses têm sido estressantes e angustiantes visto a não decisão em todas as instâncias. (Fórum Pits)

Poucos dias depois, também por meio do fórum, a coordenação nacional divulgou ofício da Secretária de Gestão do Trabalho e da Educação na Saúde, com a informação de que o Pits passaria a integrar 
os sistemas municipais de saúde, mediante repasse direto de recursos financeiros, com os profissionais sendo incorporados como equipes de PSF locais:

O Ministério da Saúde informa que está promovendo a integração e a incorporação das equipes do Pits às equipes de Saúde da Família. Isso quer dizer que está assegurada a possibilidade de permanência de todos os profissionais atualmente lotados no Pits em suas atuais equipes e local de trabal ho, mediante vinculação ao sistema local de saúde.

Na próxima semana, serão divulgados os detalhes operacionais e políticos desse processo deintegração, queserá apresentado primeiramente ao Conass eConasems. Afirmamos, no entanto, quea proposta do Ministério da Saúde, além de qualificar e fortalecer a política de atenção básica em saúde, vai assegurar integralmente os recursos financei ros atualmente comprometidos com o Pits, garantindo dessa forma as condições deremuneração dos atuais profissionais bolsistas.

Informamos ainda, que os cursos de especialização aos profissionais do Pits que ingressaram em agosto de 2003, serão mantidos e ampliados para os profissionais das equipes de Saúde da Família. (Fórum Pits)

O ofício gerou imediata reação por parte dos profissionais, no fórum do Pits. As duas mensagens a seguir ilustram bem os efeitos do comunicado sobre os médicos:

Após a leitura atenciosa do citado documento, penso oportuno tecer algumas considerações, atépara que possamos dirimir dúvidas que acredito comuns a muitos.

A primeira questão surge quando colocado que o Ministério da Saúde 'stá promovendo a integração ea incorporação das equipes do Pitsàs equipes de Saúde da Família'. A princípio, do ponto de vista estrutural, nos parece um processo de consecução aparentemente simples, se considerarmos que nesses munićpios a gestão optou por organizar a atenção básica, tendo como estratégia estruturante o Saúde da Família. Também, teoricamente, estariam facilitados os repasses financeiros, visto que esses municípios ora recebem recursos para manutenção e implementação das equipes já existentes - transferências 'fundo-a-fundo'. Minha dúvida diz respeito aos municípios onde, até então, só existem atuando as equipes do Pits, que por ironia não são consideradas equipes do Saúde da Família nem pelo Siab (SIA/SUS), e onde não é permitido o cadastramento das mesmas nesse sistema. Logo, como se daria o repasse financeiro para remuneração dos profissionais e manutenção das futuras equipes do Saúde da Família nessas localidades? Prosseguindo, o texto diz que 'está assegurada a possibilidade depermanência detodos os profissionais...'. Não suponham sarcástica minha exposição, e perdoem-me a confusão, mas não entendo como pode-se assegurar uma possibilidade. Por definição assegurar é 'garantir; afirmar 
com segurança ou certeza'. Então me pergunto como assegurar uma possibilidade? Ou seja, assegurar algo que pode ser, acontecer ou praticarse, ou não! (Fórum Pits)

Quero concordar com a interpretação do colega (...) e chamar a atenção para as entrelinhas, já que passaremos à sujeição de normas municipais que sabemos sequer existirem em muitos dos municípios atendidos pelo Pits, já que pela própria proposta inicial do programa, não estavam (mudou?) aptos a assumir equipes de Saúde da Família.

Creio ser imprescindível a representatividade dos integrantes do programa em todas as fases desta discussão, pois quando aceitamos participar do programa foi em grande parte pela credibilidade gerada pelo MS; também por crer que a experiência gerada pelo tempo de programa pode ser útil na elaboração das novas propostas (...). (Fórum Pits)

Em função das dificuldades de comunicação, por meio do fórum, com a coordenação nacional, os profissionais procuravam obter informações por conta própria sobre a continuidade do Programa e as postavam para compartilhar com os demais. Um dos profissionais postou o que denominou 'Alerta aos Pitianos', informando sobre uma reunião prestes a ser realizada entre a coordenação nacional e os gestores estaduais e municipais para decidir sobre os rumos do Programa. 0 'alerta' contou com repercussão imediata, por meio de sucessivas mensagens de apoio de outros profissionais.

Com a falta de resposta ao 'alerta' por parte da coordenação nacional, os profissionais mais uma vez se encarregaram de obter informações, dessa vez sobre os resultados da reunião, divulgando-as no fórum:

Caros colegas!!! Segundo notícia divulgada por gestores locais, o resultado da reunião dehojeem Brasília foi que, a partir dejaneiro de2004, já estaremos vinculados aos municípios (processo de municipalização). Não quero ser precipitada em nenhum comentário, uma vez que a notícia ainda é extraoficial e não sabemos de que forma o processo se deu, nem ao menos os detalhes técnicos. Peço que os colegas que tiverem informações socializem com o grupo. Aguardamos a posição da coordenação nacional do Pits (...). (Fórum Pits)

Estamos em plena Conferência Estadual de Saúde, lutando, articulando por participação social, como profissionais que somos, dando a nossa contribuição para o SUS que queremos. E hoje somos surpreendidos por muitos comentários de gestores, comentando que (...) acabou mesmo eque o nosso salário será repassado pelas prefeituras com as devidas deduções e (...) quem quiser (...) a Prefeitura decidirá os termos do contrato. (...) veja (...) novamente o que o silêncio de vocês nos proporcionou: desgosto, descrédito desmotivação (...) Meu sentimento hoje é de muita insatisfação, não valeu nada confiar!!!!!!!!!!!!!! (Fórum Pits) 
(...) o Pits deixa de existir a partir de 30 de dezembro. E estaremos nas mãos dos gestores locais. Se o município tiver o profissional do Pits no dia 01/01/04, está garantido o repasse da verba fundo-a-fundo para 0 munićpio nos pagar. Por mais 180 dias. Porém, se o município quiser dispensar este profissional e contratar outro após esta data, fica à vontade dele, o dinheiro continuará a vir. Só quem fica na corda bamba somos nós. 0 acordo agora é com os gestores municipais. (Fórum Pits)

Estamos recebendo muitas informações sobre nosso futuro e temos que organizar nossas vidas. Até agora só nos foi demonstrada total falta de respeito e consideração. A maneira com que as coisas foram feitas foi autocrática e não levaram em conta nada do que tínhamos a dizer, ou o que poderíamos acrescentar... (...). (Fórum Pits)

Somente um mês depois da reunião com os gestores estaduais e municipais, a coordenação nacional postou novo comunicado, no fórum do Pits, datado de 17 de novembro e também assinado pela secretária de Gestão do Trabalho e da Educação na Saúde, com esclarecimentos sobre problemas jurídicos que o Programa vinha enfrentando desde o início do ano, ameaçando sua continuidade. 0 comunicado, no formato de um ofício, informa que os problemas surgiram a partir de auditoria de rotina realizada, no CNPq, pelo Tribunal de Contas da União, no início de2003. Desde então, o Ministério da Saúde vinha estudando alternativas para garantir a continuidade do Programa, que, conforme esclarece 0 ofício, estaria assegurada somente até julho de 2004:

A partir do Seminário de Avaliação do Programa de Interiorização do Trabalho em Saúde ocorrido em Braślia (julho/2003), o Ministério da Saúdevem buscando alternati vas para integração do Programa às estruturas do SUS, particularmente à atenção básica, na perspectiva de fortalecer os sistemas locais de saúde.

Esse processo ganhou ainda outra emergência quando no primeiro semestre deste ano, em processo regular de auditoria no CNPq, o Tribunal de Contas da União deferiu decisão considerando irregular a gestão financeira do Programa mediante convênio entre esse órgão e o Ministério da Saúde. Na ocasião, foi determinado o prazo de 180 dias, a partir dejulho de 2003, para queo $\mathrm{CNPq}$ e Ministério da Saúde indicassem caminhos para resolução do problema.

Dessa forma a Secretaria de Gestão do Trabal ho e da Educação na Saúde juntamente com a Secretaria de Atenção a Saúde elaboraram uma proposta em caráter provisório, que previa transferência dos recursos diretamente aos municípios, buscando assegurar a permanência das equipes nos municípios. Essa proposta foi discutida em reunião realizada em Brasília no dia 24 denovembro de 2003 com os gestores municipais, coordenadores estaduais do Pits e coordenadores da atenção básica.

Simultaneamente a este processo, o Ministério da Saúde solicitou, junto ao Tribunal de Contas da União, a dilatação do prazo estabelecido para 
término do convênio. A deliberação do TCU a esse respeito ocorreu no último dia 10 de dezembro, sendo favorável à prorrogação do prazo por mais 180 dias a contar de 22 de janeiro de 2004.

Portanto, não será necessária a implementação da alternativa transitória, já que seguirá sendo possível manter a remuneração dos profissionais através das bolsas. Apesar disso, seguiremos adiante com o processo de integração do programa com a atenção básica, ea gestão das equipes será transferida aos municípios, conforme o que havíamos discutido.

Durante os próximos meses, o Ministério da Saúdeapresentará ao Conass e Conasems uma proposta de política definitiva para viabilizar a fixação de profissionais em municípios de difícil acesso e com indicadores que merecem atenção diferenciada. (Fórum Pits)

Ao longo de 2003, até a extinção do Programa, em julho de 2004, houve uma série de contratempos ocasionados ou agravados por esse cenário. Foram contratempos de todas as ordens, que interferiram em vários aspectos do funcionamento do Programa, desde atraso no pagamento das bolsas, suspensão de diárias e transporte para que os profissionais pudessem freqüentar o curso de especialização nas capitais, até o agravamento do não cumprimento da contrapartida municipal. Foi um período de intensa troca de mensagens, no fórum do Pits, entre os profissionais, relatando os problemas enfrentados:

Colegas do Pits III. Esta mensagem vai para aqueles que por ventura estão tentando realizar o curso de especialização. Tomamos conhecimento da suspensão das diárias, para quem está fazendo o curso deespecialização. Gostaria de saber do posicionamento dos demais participantes que estão em condições semelhantes a minha. No meu caso, será impossível de continuar, já estou bancando meus gastos aqui em [nome do município], agora ter que gastar com diárias, não dá, vou terminar pagando para trabalhar. (Fórum Pits)

É apenas uma impressão, ou estamos mesmo com atraso no pagamento de nossos salários??? (...). (Fórum Pits)

Pois é, aqui estamos com mais um mês de atraso... (Fórum Pits)

Mas, desde o informe oficial, em novembro, de que o Programa só se manteria até julho de 2004, a tônica das mensagens do fórum foi, essencialmente, a confirmação desse prazo final, as condições de trabalho até lá e o destino dos profissionais e suas angústias e ansiedades em relação ao futuro.

A coordenação nacional respondeu aos profissionais no fórum, em março de 2004, com dois comunicados. O primeiro, no formato de ofício, 


\section{esclarece algumas questões acerca do curso de especialização. 0 segundo faz uma espécie de balanço da trajetória de gestão do Programa:}

O Programa de Interiorização do Trabalho em Saúde/ Pits éuma iniciativa desenvolvida pelo Ministério da Saúde, desde 2001, em parceria com as Secretarias Estaduais e Municipais de Saúde e o Consel ho Nacional de Desenvolvimento Científico eTecnológico/ CNPq, com o objetivo depropiciar a atenção à saúdeem municípios que, por dificuldade de acesso ou escassez extrema de recursos, não contavam com profissionais de saúde para 0 desenvolvimento da atenção básica.

O Programa foi concebido com caráter transitório e como indução aos gestores municipais para implantação e reorganização de suas ações de saúde, considerando a estratégia da saúde da família.

O prazo para o término do convênio com o CNPq firmado ainda no governo anterior foi até junho de 2004.

Durante o primeiro semestre do ano de 2003 o Programa foi mantido em sua estrutura original, tendo havido, inclusive, processo sel etivo específico para médicos, com o objetivo de completar equipes que só contavam com o profissional enfermeiro.

Simultaneamente foi desencadeado processo de avaliação do Programa nos estados que culminou na realização de um Seminário de Avaliação (julho/ 2003 - Brasília), com objetivo de identificar em conjunto com todos os atores envolvidos, os problemas e avanços, bem como estratégias para 0 enfrentamento das dificuldades.

Dentre os problemas apontados durante o Seminário destacamos a desarticulação do Programa com as demais estruturas do SUS, particularmentea atenção básica, verticalização/ centralização das decisões no âmbito federal sem levar em consideração a realidade local levando ao estabelecimento de vínculo preferencial dos profissionais com o Ministério da Saúde em detrimento dos gestores locais.

A partir desses resultados, iniciamos o processo de reformulação do Programa com o objetivo de integrá-Io às estruturas do SUS, particularmente à atenção básica, desencadeando a sua transição para ossistemas municipais de saúde buscando assegurar a permanência das equipes nos municípios.

Esta necessidade ganhou ainda outra emergência quando, no primeiro semestre de 2003, através de auditoria regular no CNPq, o Tribunal de Contas da União deferiu decisão considerando irregular a gestão financeira do Programa através de convênio entre esseórgão e o Ministério da Saúde, determinando o prazo de 180 dias, a partir de julho de 2003 para que 0 CNPq e Ministério da Saúde apontassem proposta para resolução do problema. Dessa forma, a Secretaria de Gestão do Trabalho e da Educação na Saúde, juntamente com a Secretaria de Atenção à Saúde, elaboraram uma proposta em caráter provisório, garantindo a permanência das equipes nos municípios, que foi discutida em reunião realizada em Brasília no dia 24 de novembro de 2003 com os gestores municipais, coordenadores estaduais do Pits e coordenadores da atenção básica. 
Simultaneamentea este processo, o Ministério da Saúde solicitou junto ao Tribunal deContas da União a dilatação do prazo estabelecido para término do convênio. A deliberação do TCU ocorreu em dezembro de 2003, sendo favorável à prorrogação do prazo por mais 180 dias a contar de 22 de janeiro de 2004.

Portanto, a Secretaria de Gestão do Trabalho e da Educação na Saúde, juntamente com a Secretaria Executiva e Secretaria de Atenção à Saúde, deverão apresentar ao Conass e Conasems até março de 2004 uma política definitiva que viabilize a fixação de profissional em municípios de difícil acesso e com indicadores que merecem atenção diferenciada, através da definição de critérios que propiciem um financiamento diverso das ações de atenção básica organizadas pela estratégia Saúde da Família.

Concluindo, estamos aguardando a aprovação da proposta em reunião da Tripartite que deverá ser ainda em março/2004; o Programa será integrado ao PSF e esses municípios terão um financiamento diferenciado, considerando os critérios definidos. Além dos municípios do Pits serão incluídos municípios detodos os estados desde que obedeçam a esses critérios. Estamos aguardando parecer da Tripartite para que possamos oficializar as definições. (Fórum Pits)

A partir de então, os profissionais passaram a demonstrar, no fórum, sua ansiedade por obter informações acerca da reunião da Tripartite, que acabou sendo transferida para o final de abril. Como o retorno a essa solicitação, por parte da coordenação nacional, mais uma vez demorou, os profissionais manifestaram sua insatisfação com o que consideraram descaso e desrespeito com sua situação, e compartilharam suas dúvidas:

Realmente (...), estamos numa situação muito desconfortável e nem um pouco saudável. Não consigo entender o porquê deste silêncio todo da Coordenação. Precisamos resolver nossas vidas (...) pela segunda vez peço à coordenação que não mais adie a comunicação oficial do nosso destino (...). (Fórum Pits)

É lamentável a falta de humanidade e eficiência desta coordenação para com profissionais que saíram de seus estados para tão longe na tentativa de trabalhar por uma saúde pública de melhor qualidade (...) Fica aqui 0 meu protesto e desapontamento com a condução final deste programa, que com certeza foi um marco importantena história da saúde pública do país, por ter combatido o problema dos recursos humanos em regiões carentes e de difícil acesso (...). (Fórum Pits)

Mais uma vez, o esclarecimento veio primeiro por meio dospróprios profissionais, sem que a coordenação nacional tivesse se pronunciado: 
Recebi da Coordenadoria do Pits [nome do estado] a seguinte mensagem: 'Comunicação sobre o Pits (...) Senhores Profissionais, Estamos nos aproximando do vencimento do contrato de bolsista do CNPq (Pits) que será em 30/06/2004. A coordenação nacional do Pits nos informou que a nova proposta de continuidade de tratamento especial aos municípios com IDH abaixo de 0,7 passou na Tripartite no último dia 29/ 04/2004. A proposta ficou assim: todos os municípios contratados com o Pits e os munićpios com a população $=30.000$ habitantes receberão incentivo por equipe do PSF cadastrada com $50 \%$ a mais do valor inicial. Ex.: muniápio com $70 \%$ de cobertura do PSF recebe hojeX e passará a receber Y. Essa nova modalidade entrará em vigor a partir de 01/07/2004' (...). (Fórum Pits)

Colegas, é profundamente preocupante a forma com que vem sendo conduzido o término do Pits. Pois a coordenação do Pits no [nome do estado], conformecomunicado do colega (...) , já comunicou aos profissionais a data do fim do Pits, bem como as decisões tomadas na Tripartitee, mesmo assim, persiste 0 silêncio da coordenação nacional no tocante ao assunto em pauta, cujo interesse dos profissionais é muito relevante. (...)

Relaciono preocupações pertinentes que não poderão, de forma alguma, ser desconsideradas:

- a diferenciação salarial existente hoje em um mesmo município entre o salário do Pits e PSF;

- 0 atraso salarial dos profissionais do PSF, em sua maioria;

- autonomia do município para contratar profissionais;

- a não existência de uma política nacional de remuneração dos profissionais do PSF para execução de uma mesma atividade em um programa (estratégia) de âmbito nacional e com os mesmos objetivos (melhoria de indicadores, assistência integral e humanizada, acessibilidade, prevenção de doenças e promoção de saúde e estímulo ao controle social etc);

- educação continuada.

Considerando a situação em curso, ou seja, aproximação do término do Pits concomitante com o prazo máximo para contratação de profissionais (deacordo com a lei eleitoral), bem como a indefinição dos gestores no que diz respeito a contratar os profissionais do Pits, concluímos que estamos correndo um grande risco de ficarmos excluídos e com pouquíssimas opções (relação oferta x procura) (...). (Fórum Pits)

Em função desse diagnóstico, os profissionais do Pits começaram a se mobilizar, por meio do fórum, para tentar evitar a extinção do Programa:

Caros colegas, aceitando sugestão de um colega de trabalho que diz para que todos os nossos prefeitos enviem carta pedindo a continuação do Pits, 
endereçada à coordenação nacional do Pits, à coordenação estadual e ao J ornal [nome do jornal], quem sabe aí então poderíamos ter uma resposta mais efetiva. Vamos aceitar essa sugestão???? (Fórum Pits)

Vamos promover reuniões estaduais para discussão sobre os rumos do Pits? Embora estejamos em situação irregular, pois muitos permanecem há quase três anos sem vínculo ou direitos empregatícios, ainda acreditamos que o Pits possa ser uma melhor opção, se comparado ao contrato feito com algumas prefeituras, acostumadas a não cumprirem os seus compromissos, pagarem mal a maioria dos seus empregados e atrasarem 0 salário de seus funcionários. Seria o tempo, talvez, de tentarmos discutir saídas para o impasse. Sabemos que o Pits só existiu porque determinadas cidades estavam com a saúde muito deficiente. Então, o que melhor fazer para darmos continuidade às ações realizadas até aqui? Uma proposta seria a continuação do Pits até dezembro. É possível? Porém, como proceder após esta data? 0 ideal seria continuarmos nas cidades em que fomos lotados, porém sob contrato empregatício. Se muitos municípios não apresentam condições para nos oferecerem a tranqüilidade de uma remuneração apropriada e estável, como contornar isto, sem ferir os princípios do SUS? (...). (Fórum Pits)

O que está ocorrendo é política, logo, penso que o nosso alvo são os senhores deputados estaduais, federais e senadores da oposição, aí sim, é possível, que haja barulho e desta maneira poderemos ter alguma chance (...). (Fórum Pits)

Concordo que o CNPq visa à pesquisa e não ao trabalho, que desde 0 início sabíamos do término, mas peço aos coordenadores que implantem um novo Programa de Interiorização de Profissionais, pois este povo brasileiro precisa muito e está muito longe do SUS que queremos. O SUS que permanece no papel para muitos, aqui se vê colocar fezes de papagaio no ouvido quando setem dor, tomar urina decachorro quando tem diabetes, para tosse fezes de cachorro bem clarinhas, e por aí afora. Eu tenho certeza, e vi sentindo na pele, que precisamos fazer valer pelo menos um princípio do SUS neste país: eqüidade. Saúde é direito do Povo e dever do Estado. Aguardamos com ansiedade notícias oficiais quanto a prazos e outros pormenores. Sei que muitas vezes opiniões neste fórum podem fazer um coordenador, que tem o poder nas mãos, se questionar, repensar, dialogar, voltar atrás, resgatar princípios, acredito no bom senso deste governo. (Fórum Pits)

Somente no final de maio a coordenação nacional respondeu, no fórum do Pits, às inquietações dos profissionais, com a divulgação de um novo ofício:

Dirigimo-nos à Vossa Senhoria para informar quea proposta de Incentivo ao Programa de Saúde da Família-PSF para pequenos municípios foi aprovada na reunião da Comissão Intergestores Tripartite, de 29 de abril de 2004. 
Por decisão do Tribunal de Contas da União (TCU), a remuneração dos bolsistas do Pits/CNPq somente poderá ser mantida pelo Ministério da Saúde até 30 de junho de 2004. Mediante o exposto, orientamos que as Coordenações Estaduais de Atenção Básica/ PSF e os municípios envolvidos encaminhem, com urgência, solicitação para a próxima reunião da Comissão Intergestores Bipartite-CIB do seu Estado, proposta dequalificação de equipes de Saúde da Família no número correspondente ao número de equipes Pits hoje existentes em cada município (ad referendum).

A aprovação de qualificação de equipes pode considerar, inclusive, as equipes incompletas do Pits. Essa medida visa dar agilidade ao processo de transição das equipes do Pits para equipes da Saúde da Família. Após a aprovação na CIB, os estados devem informar ao Ministério da Saúde para publicação. A partir daí, os municípios devem contratar os profissionais das equipes e cadastrá-los via Siab como equipes da Saúde da Família. Em relação às equipes incompletas, à medida que forem sendo completadas, devem ser informadas como equipes da Saúde da Família, passando a receber os recursos correspondentes.

Sugerimos que a qualificação pela CIB estabeleça um prazo de 60 ( sessenta) dias para regularização do processo, com encaminhamento do plano elaborado pelo munićpio e aprovado pelo Conselho Municipal de Saúde.

Salientamos a necessidade do comprometimento de todos os gestores para que não haja descontinuidade na atenção à saúde prestada à população e de quea experiência e o acúmulo dos profissionais do Pits sejam levados em conta. (Fórum Pits)

O ofício provocou reações de desânimo e desesperança dos profissionais do Pits, manifestadas no fórum, particularmente entre os que ainda acalentavam a expectativa de que o Programa não viesse a ser extinto:

0 ofício enviado nos deixou com mais tristeza, desmotivados para prosseguir nosso trabalho. São sabidas, desde janeiro, as decisões que porventura seriam tomadas na reunião da Tripartite e do prazo do TCU. Porém, achávamos que o desfecho seria outro, quem sabe uma possível prorrogação até dezembro, ou alguma ONG, pois o período eleitoral se aproxima, e a nossa realidade é de que prevalecem aqueles que se comportarem como verdadeiros cabos eleitorais. Não temos nenhuma garantia desermos contratados, nem tão pouco de recebermos nosso salário em dia. Será que depois de tudo o que enfrentamos e de tanto investimento, não merecemos no mínimo isso?! (...) Acredito que vamos passar por um momento de regressão na saúde, já que as propostas destes municípios onde nos encontramos atualmente não estão oferecendo uma proposta salarial digna, o que levará o profissional a sair do município e pela precariedade exposta, o município poderá até ficar descoberto de 
profissionais, acarretando novamente piora desses indicadores. Será queé isso que a comunidade quer? Que o MS quer? Vocês não estão pensando nas conseqüências dessas decisões verticalizadas? Lamento muito e acho que devemos repensar e buscar outro caminho, ampliar nossos horizontes. (Fórum Pits)

Manifestação do Pits/ [ nomedo estado] - Redigida na penúltima reunião de [nome do município].

Nós, enfermeiros emédicos, especialistas em Saúde da Família, dirigimos nossas palavras de preocupação ealerta quanto à desativação do Programa deInteriorização do Trabalho em Saúde(Pits), responsável pelo atendimento de milhares de famílias, em todo o Brasil. Causa-nos estranheza e extrema preocupação a inativação de um programa em que foram investidos grandes esforços para a capacitação dos vários profissionais de saúde e colocação destes nos vários municípios brasileiros, possuidores de indicadores desaúde ruins e carentes de profissionais de saúde de nível superior. Fomos selecionados pelo Ministério da Saúde e treinados sob a supervisão de universidades de prestígio nacional, a fim de melhorarmos os principais indicadores de saúde dos municípios assistidos pelo Pits. Hoje, em plena época de eleições políticas, em um período tão difícil para encontrarmos boas propostas detrabalho, estamos sendo 'exonerados' (...) A contrapartida da coordenação nacional do Programa de Interiorização do Trabalho em Saúde (Pits) éde incorporação dos profissionais do Pits ao sistema de saúde dos municípios em que fomos lotados, sendo que nossos salários seriam pagos, a partir de julho, pelos gestores municipais. Conseqüentemente, ficaremos à mercê de administrações municipais que talvez não cumpram, de modo regular, os seus compromissos salariais para com os seus novos contratados (...). (Fórum Pits)

Mas a decisão de extinguir o Pits, incorporando os profissionais aos sistemas municipais de saúde, estava tomada e já se mostrava irreversível. Em 18 de junho de 2004, a coordenação nacional divulgou, no fórum, novo ofício com detalhes dos procedimentos operacionais para a finalização das atividades do Programa.

Diante da irreversibilidade da decisão e da contundência do ofício, restou aos profissionais deixarem seu desabafo registrado no fórum. Um desabafo lúcido, que chama a atenção para o fato de o Pits ter, na realidade, estabelecido uma relação de trabalho entre o Ministério da Saúde, o CNPq e os profissionais, com todas as implicações jurídicas daí decorrentes, apontadas inclusive pelo TCU. Um desabafo que evidencia aspectos determinantes para iniciativas destinadas à interiorização de médicos e que serão explorados nas conclusões deste capítulo:

É lamentável a falta de seriedade das instituições, nesse país. 0 que 0 Ministério da Saúdefez com o pessoal do Pits, principalmente, o Pits III, foi 
o que se chama quebra de contrato. (...) É preciso informar aos demais participantes queélícito elegal processar o Ministério da Saúde por quebra de contrato (...). (Fórum Pits)

A coordenação nacional (...) estará aprofundando cada vez mais a tão abominável precarização do trabal ho em saúde (tão discutida no seminário nacional de avaliação do Pits e repudiada pela atual gestão do Ministério da Saúde). (...) Pela valorização, respeito edignidadeaos recursos humanos do SUS. (Fórum Pits)

Prezados senhores que acreditaram no Pits. (...) me gerou um sentimento de revolta e vergonha, por saber que certos programas dependem de elementos que se dizem brasileiros, e mais a sensação de mais uma vez ter sido vencido e enganado pelo sistema onde predomina a corrupção e o desmando. Prezados colegas, cidadãos brasileiros, pais defamília, idealistas ( otários no nosso país), pagadores de impostos, que saíram dos seus lares, estados, do aconchego dosfamiliares, acreditando em um sonho, etambém por uma remuneração um pouco menos indigna do que normalmente se paga a quem trabalha sério nessa nossa nação. Quem não pensa, ao chegar em uma comunidade carente aqui do nosso Nordeste, que vai melhorar alguma coisa para aquelas pessoas, que estão em um limite tênue entre ser um ser humano ou qualquer outro animal? Quem não se realiza com um sorriso de uma criança queantes chorava de dor ou de fome (obs.: o pessoal que tá no DF não sabe queisso existeaqui não, acha que só tem na África)? Quem não sesenterealizado depois de um dia exaustivo detrabalho embaixo de um sol de mais de 40 graus, ver que uma, apenas uma pessoa, vai dali em diante ferver a água para beber? Fiquem certos e orgulhosos de que quem comprou essa idéia são os verdadei ros brasileiros, parabéns, modéstia à parte, palmas para nós, nosso ego precisa de massagem de vez em quando. Nós somos aqueles que vão à luta, como dizia o poeta. Após expor meus sentimentos nesse breve momento (não sei se vão deixar ficar no fórum muito tempo), quero convocar todos os participantes que se sentem desrespeitados como eu, a mover uma ação contra quem de direito (MS/ CNPq), para quenovos episódios semel hantes a esses não venham novamente a acontecer. Penso que esse éo único meio para tentar moralizar essa nossa pátria. (Fórum Pits)

Sons do silêncio. (...) A rigor, em 2001, quando muitos profissionais ingressavam no Programa de Interiorização do Trabalho em Saúde, a maioria não tinha clareza do que realmente os aguardava. Eu pelo menos não. Muito menos que dois anos depois, próximo ao terceiro, ainda estaria inserido no mesmo projeto. M enos ainda, queestaria sentado nestemomento tentando compartilhar minhas angústias, ou melhor, quem sabe, mágoas (...) E agora J osé? Naqueles idos, sentia-me como muitos, meio desbravador, meio cidadão do mundo, de quem o mundo cobra al go mais, além de 'ficar com a boca cheia de dentes esperando a morte chegar'. Grande Raul! E agora Maria? Disseram-nos que estavam nos destinando a locais onde os indicadores de saúde estavam muito abaixo do esperado, quanto mais desejados. Uma meia verdade incontestável. 0 que não nos foi dito, em 
silêncio oportuno cumpliciado por nossa surdez eufórica, é que um outro indicador, tão ou mais aterrador estaria nos esperando, ao qual vamos denominar inaptidão gerencial. Característica, aliás, degrande parte desses municípios, onde imperam oligarquias decadentes há décadas - não me desculpem pelo trocadilho proposital. Injusto se não ressaltássemos a máxima de que a toda regra cabe exceção. Caso exista nesse caso. (...) À época, escutamos outros sons em meio ao silêncio. Sons que entendemos bem e aos quais não vou meater. Afinal, asúltimas eleições presidenciais já têm um bom tempo. Também não me aterei ao som turbulento promovido pela clara verticalização do processo. Veio à mente se não 0 estamos escutando novamente. Não sei. Penso que muitos devem estar se perguntando: e agora J osé? E agora Maria? Muito do pouco que fizemos, o conseguimos em função de uma certa 'autonomia' frente ao caos estabelecido pela mesma oligarquia a que querem nos subordinar (...). (Fórum Pits)

Tenho trabalhado em muniápios do interior do Brasil desdequeme formei em 1994, sendo que desde 1998 como médico do PSF. 0 que me fez aderir ao Pits em 2001 não foi 0 valor da bolsa, mas sim o conjunto de medidas complementares que visavam compensar as deficiências vivenciadas por quem mora e trabalha no interior, principalmente às relacionadas à educação continuada, à qualidade de vida e às condições de trabalho. 0 Ministério da Saúde garantiu, expressamente, que os profissionais do Pits teriam direito a curso de especialização, educação continuada, conectividade e tutoria, receberiam o salário em dia, teriam seguro de vida, moradia digna e boas condições de trabalho, ou seja, condições de vida e trabalho necessárias para que pudessem exercer dignamente a medicina nos mais longínqüos municípios do país. Condições essas que não existiam no PSF daquela época eque continuam não existindo atualmenteno PSF da grande maioria das cidades do interior do Brasil. Posso dizer que o Pits funciona, com alguns problemas, mas funciona. Fiz o curso de especialização, não fiz a educação continuada à distância, a conectividade funciona relativamente bem, os tutores não receberam das secretarias estaduais de saúde condições para exercerem adequadamente suas funções, recebo meu salário em dia (ainda não me esqueci que estão faltando os $10 \%$ relativos a julho de 2003), minha moradia ainda está longe de ser digna, as condições de trabalho ainda não são as ideais, atéhojenão recebi o meu kit de materiais (está em processo de licitação desde 2001), o kit da farmácia básica não dá nem para o básico, mas enfim, consegui, juntamente com minha equipe, fazer um bom trabalho.

Com a chamada institucionalização eintegração do Pits ao PSF, o Ministério da Saúderepassará apenaso incentivo diferenciado para o PSF dos munićpios selecionados, que farão com os recursos o que bem entenderem, como na verdade historicamente sempre o fizeram, e nós passaremos a ser reféns dos prefeitos e secretários municipais de saúde, uma vez que sabemos que as secretarias estaduais de saúde não têm recursos financeiros nem humanos suficientes para fiscalizarem o funcionamento das equipes do PSF. Por isso, grande parte dos profissionais do Pits, principalmente os médicos, já 
abandonaram o Programa, fazendo com que a maioria das equipes esteja apenas com o profissional de enfermagem (resistindo bravamente) ou simplesmente já tenham deixado de existir, o que influi negativamente nos indicadores de saúde dos municípios contemplados com o Pits. Na minha opinião o Pits está no caminho certo, mas com certeza precisa de ajustes. Porém acredito que a solução encontrada pela coordenação nacional do Programa não éa mais adequada, sendo na verdade um retrocesso, pois em vez deestimular a interiorização demais profissionais de saúde, está fazendo com que os profissionais já interiorizados retornem para as capitais. Entretanto, no íntimo da minha militância, espero estar enganado (...). (Fórum Pits)

Ao ser entrevistada para o estudo da Rede Observatório de Recursos Humanos em Saúde, a então secretária de Gestão do Trabalho e da Educação na Saúde esclareceu que a decisão de extinguir o Pits e incorporar os profissionais aos sistemas municipais de saú de foi tomada, fundamentalmente, pela impossibilidade jurídica de mantê-lo no formato de um programa de interiorização (Maciel Filho, 2007). Impossibilidade decorrente do modelo adotado quando de sua concepção, considerada inadequada, do ponto de vista legal, pelo TCU, por acarretar uma relação de trabalho precária. Ainda segundo a secretária, foram estudadas outras alternativas, inclusive do tipo serviço civil voluntário, mas que se mostravam inexeqüíveis dentro dos prazos definidos pelo TCU e pelo Ministério Público do Trabalho para o encerramento do modelo Pits.

Por fim, o desempenho do Pits como um todo - considerando-se aí todo o seu processo de funcionamento e, conseqüentemente, a atuação da coordenação nacional como gestora máxima - foi considerado pela maioria dos médicos participantes do Programa, na avaliação promovida pelo Ministério, como regular (68,8\%). Apenas 18,8\% o consideraram 'bom', e para $12,5 \%$ foi 'insuficiente' (Brasil, 2002e).

\section{Atuação das Coordenações Estaduais}

A participação dos estados no Pits iniciou-se quando da sua formulação, por meio de representação na figura do próprio presidente do Conass. A discussão se estendeu para a Comissão Intergestores Tripartite (CIT), onde foram debatidos os possíveis mecanismos e alternativas para promover a fixação de profissionais de saúde nos municípios mais carentes do país. No entanto, em que pese essa participação, na avaliação do então presidente do Conass, em entrevista para o estudo da Rede Observatório de Recursos Humanos em Saúde, 
O Ministério da Saúde privilegiou a relação direta com os municípios, como ocorreu em muitos casos do próprio processo de municipalização. Quando as secretarias estaduais de saúde procuravam os municípios, verificavam que eles já estavam negociando benefícios e estímul os diretamente com o Ministério. (Maciel Filho, 2007: 187)

Essa estratégia foi considerada por ele como equivocada:

Os estados foram consultados muito mais para referendar a proposta de criação do Pits do que para interferir efetivamente nos seus delineamentos e rumos. Houve, por exemplo, discrepância entre a lista de municípios indicados pelas secretarias estaduais de saúde para serem contemplados pelo Programa, por avaliação das equipes técnicas, e a lista do Ministério. (Maciel Filho, 2007: 187)

Com a criação da coordenação nacional, foram criadas também coordenações nos estados, vinculadas às secretarias de saúde, sendo os coordenadores escolhidos pelos respectivos secretários. As coordenações estaduais tinham as seguintes atribuições, definidas pela Portaria n. 227/GM :

1.2.1. articular, junto aos Pólos de Capacitação em Saúde da Família e às Instituições de Ensino Superior, a supervisão e a tutoria dos profissionais participantes do Programa;

1.2.2. garantir os deslocamentos intermunicipais dos profissionais integrantes do Programa no desenvolvimento de suas atividades;

1.2.3. planejar e acompanhar junto à Secretaria Estadual de Saúde a referência para o atendimento de pacientes encaminhados para especialidades, emergências ou internações;

1.2.4. operacionalizar o processo de habilitação dos municípios no Programa;

1.2.5. acompanhar, supervisionar e avaliar a sua implantação e o funcionamento do Programa;

1.2.6. garantir hospedagem de trânsito e o transporte dos profissionais entre o estado e o município de destino; 
1.2.7. supervisionar junto às Prefeituras Municipais a hospedagem, alimentação e transporte dos profissionais; e

1.2.8. apoiar a Comissão Nacional de Seleção no processo seletivo no âmbito do respectivo estado. (Brasil, 2001b)

O desempenho das coordenações estaduais foi muito variado. Segundo dados da avaliação promovida pelo M inistério da Saúde, metade dos profissionais participantes do Pits considerou o desempenho da respectiva coordenação estadual como 'bom'. Outros 31,3\% avaliaram a coordenação do Programa em seus estados como 'regular' e 18,8\% como 'insuficiente' (Brasil, 2002e).

No caso de dois estados, Acre e Tocantins, os gestores estaduais, por iniciativa própria, concederam um incentivo financeiro a mais para os médicos, incidindo sobre o valor da bolsa paga pelo Pits, o que resultou em ampliação do preenchimento das vagas destes estados, da ordem de 70\% (Brasil, 2002e, 2002g).

Ao ser entrevistado para o estudo da Rede Observatório de Recursos Humanos em Saúde, o ex-secretário de Políticas de Saúde, um dos formuladores do Pits, admitiu que: “( ...) em alguns estados, o envolvimento da Secretaria Estadual apresentou algum grau de dificuldade, ou por discordância acerca da condução do Programa ou por dificuldade operacional mesmo (...)" (Maciel Filho, 2007: 188).

Esses fatores apontados pelo ex-secretário e as características da inserção dos estados na formulação do Pits, conforme descritas pelo representante do Conass, podem explicar as raras referências feitas pelos profissionais às coordenações estaduais, no fórum do Pits. Quando há alguma referência, nas 352 mensagens ali disponíveis, o que se revela é exatamente o pouco envolvimento dos estados no desenvolvimento do Programa. Parece que este envolvimento teve um caráter muito mais administrativo do que propriamente político e de efetivo comprometimento com a proposta.

Isso trouxe implicações para um dos mais importantes fatores para a boa prestação de atenção à saúde nos municípios contemplados pelo Programa e que figura entre as já citadas atribuições das coordenações estaduais: o planejamento e acompanhamento do sistema de referência para 0 atendimento de pacientes encaminhados para especialidades, emergências ou internações. 
A ex-secretária de Gestão do Trabalho e da Educação na Saúde, responsável pela gestão política do Pits a partir de 2003, em entrevista para o mesmo estudo, destaca esse aspecto: “ (...) Eu acho que esse é um dos sérios problemas, essa coisa da relação com o resto do sistema, com a Secretaria Municipal de Saúde, com os serviços de saúde em si. Como era uma relação direta com o M inistério, era um problema complicado em termos da descentralização, em termos da estrutura" (Maciel Filho, 2007: 188).

\section{Atuação dos Municípios}

Assim como os estados estiveram representados pelo Conass no processo de formulação do Pits, também os municípios contaram com a representação do Conasems. Tal como o Conass, essa representação se deu por meio do presidente do Consel ho, que, ao ser entrevistado para o estudo da Rede Observatório de Recursos Humanos em Saúde, declarou que a inserção da instância municipal no processo de formulação e gestão do Pits se deu em função de uma necessidade de pactuação por parte do Ministério, que construiu uma proposta para o Programa onde o Conasems esteve inserido muito mais no sentido de "(...) pactuar criticamente (...) do que uma construção, uma co-gestão desse processo" (Maciel Filho, 2007: 189).

Observando-se as atribuições municipais, definidas pela Portaria n. 227/GM, que criou o Programa, percebe-se que realmente são atribuições de caráter essencialmente operativo:

4.1. promover a organização da atenção básica em seu território, contratando, na forma da lei, os demais profissionais necessários a sua consecução;

4.2. garantir al imentação e moradia em condições de conforto e higiene adequadas, de forma individualizada e exclusiva, aos participantes do Programa em atividade no seu território;

4.3. assegurar a disponibilidade de unidade básica de saúde para o desenvolvimento das atividades inerentes ao Programa, provendo a sua respectiva manutenção e limpeza;

4.4. fornecer os equipamentos necessários para a prestação da atenção básica;

4.5. viabilizar a realização de exames laboratoriais básicos de diagnóstico; 
4.6. assegurar o fornecimento de vacinas, medicamentos essenciais e outros insumos básicos para o funcionamento da unidade;

4.7. garantir o quantitativo necessário de auxiliares de enfermagem e de agentes comunitários de saúde, observadas as diretrizes do Pacs;

4.8. assegurar transporte adequado para a transferência de pacientes, de acordo com a indicação médica;

4.9. assegurar suporte necessário para a referência e a contrareferência;

4.10. garantir o transporte dos integrantes do Programa para o desenvolvimento de suas atividades no município. (Brasil, 2001b)

Esse caráter mais operativo, atribuído pelo Ministério da Saúde à participação municipal no Pits, em detrimento de uma relação de cogestão, como ressaltado pelo então presidente do Conasems, pode explicar algumas características e problemas que o Programa apresentou ao longo de seu desenvolvimento, o que acaba sendo confirmado, quando se analisa o documento "Tópicos da política de desenvolvimento de recursos humanos para o Sistema Único de Saúde", apresentado pelo Ministério da Saúde no Seminário Internacional sobre Política de Recursos Humanos em Saúde, promovido pela Opas em novembro de 2002. 0 documento aponta as fragilidades do Pits relacionadas com a atuação dos municípios, que seriam:

- desconhecimento, por parte de alguns gestores municipais, dos princípios do Pits e da Estratégia de Saúde da Família, o que pode comprometer o bom desempenho de ambos os programas naquelas localidades;

- o não cumprimento da contrapartida municipal pelos gestores, levando ao não atendimento das condições especificadas no Pits; - dificuldades em estabelecer um sistema de atendimento à população de referência especializada e contra-referência. (Brasil, 2002h: 19)

Ora, como municípios com sistemas de saúde incipientes e precários podem conhecer os princípios do Pits e da Estratégia de Saúde da Família sem que sejam incorporados em um processo efetivo de co-gestão, 
devendo limitar-se a cumprir atribuições de caráter fundamentalmente operativo?

0 representante do Conasems destaca, em sua entrevista, aspectos essenciais da relação entre entes gestores, alertando para os riscos da verticalização:

O Pits é uma boa política para ser analisada de como a radicalidade da descentralização no Brasil tem dificuldade de conviver, inclusive hoje, com programas híbridos (...). O Pits não chega a ser um Programa oblíquo, sabe, então o que eu quero dizer é que é importante a análise dele, porque o que é que vai acontecendo: à medida que ele vai sendo implantado, vai ressaltando dentro dele o grau de vertical ização e os conflitos da verticalização começam a aparecer. Então uma coisa que os secretários, num primeiro momento aceitaram, que era uma coisa que resolvia os problemas deles, passou a criar outros problemas, que fugiam da governança dos secretários justamente por esse grau de verticalidade. Então ele é um bom Programa para analisar que nenhuma política num país hoje, qualquer política, ela para ter sustentabilidade, na pior das hipóteses, ela tem que ser oblíqua, porque senão é isso, ela perde força (...). (Maciel Filho, 2007: 190)

Os profissionais do Pits também identificaram esse problema, debatendo no fórum a precária participação dos gestores municipais nas definições do Programa. 0 interesse dos profissionais pelos aspectos de gestão do Programa e do sistema local de saúde estendeu-se para além do discurso, com iniciativas concretas para fortalecer a gestão da saúde nos municípios do Pits e o controle social, como os exemplosa seguir, do fórum:

Realizamos a nossa 2a reunião para a implantação do nosso conselho local de saúde. Houve a participação de vários segmentos sociais e de companheiros bastante animados para tal empreendimento. Em nossa 3ạ reunião, marcada para o dia (...), esperamos contar com a presença de nossa secretária de saúde. Com isto, esperamos estar cada vez mais organizados para, democraticamente, expressarmos efetivamentea vontade da comunidade, visando à conquista de valores substanciais para 0 aprimoramento da saúde de nossa cidade. (Fórum Pits)

Encaminhamos, abaixo, relatório anual às comunidades de áreas de abrangência e influência da nossa equipe de PSF, afixado na entrada de nossa unidade de saúde: 'Relatório Anual relativo aos meses de junho/ 
2002 a junho/ 2003'. Estamos completando dois anos do Programa de Interiorização do Trabalho em Saúde (Pits), no município de [nome do município] (...). Após organizarmos, junto com a Secretaria de Saúde do município de [nomedo munićpio], os vários serviços eprogramas deatenção primária, tendo como estratégia orientadora o Programa de Saúde da Família, demos ênfase ao aprimoramento das várias unidades de saúdee à otimização da integração destas no contexto de saúde da comunidade local. Foi dada importância ao trabalho conjunto com os diversos representantes da comunidade, inclusos aí o Conselho Municipal deSaúde, diversas escolas, creches, além deoutras entidades. 0 atendimento de puericultura epediatria, por exemplo, foi descentralizado, sendo levado para as escolas e creches. (Fórum Pits)

Vocês devem estar lembrados queum dos critérios deelegibilidade das cidades do Pits era apresentarem sistema de saúde com organização e administração insuficientes. Todas as mudanças que conseguimos nos municípios foram consequêencia do empenho pessoal dos profissionais envolvidos, eaté mesmo as mudanças ocorridas na administração e organização do serviço de saúde foram em conseqüência da atuação da equipe do Pits, e principalmente pela atuação, de certa forma, 'desvinculada' da administração local. (...) Penso que uma das atribuições colocadas no Edital do Pits ena Bolsa com o CNPQ, queéa de que os profissionais do Pits devem colaborar na implementação e organização dos serviços de saúde, deveria ser mais trabalhada e mais fortalecida, pois foi essa atribuição, na minha opinião, que deu um caráter mais resolutivo ao programa. (Fórum Pits)

De modo geral, segundo a avaliação promovida pelo Ministério da Saúde e referida nas seções anteriores, os profissionais do Pits não tinham dificuldade de acesso ao secretário municipal de saúde (Brasil, 2002e).

Já as condições de trabalho oferecidas pelos gestores municipais, como cumprimento da contrapartida, foram, em muitos casos, insatisfatórias. A maioria dos profissionais que responderam à avaliação do Ministério $(77,2 \%)$ relatou contar com uma unidade de saúde para a execução das atividades inerentes ao Programa. Na maior parte dessas unidades, havia sala de recepção (70,7\%), consultório médico (78,9\%) e sala de procedimentos básicos (65,0\%), mas somente em cerca de metade delas (52,0\%) havia sala de vacinas. Quase $70 \%$ dos profissionais informaram não haver material e nem equipamentos suficientes para atendimento (Brasil, 2002e).

O suporte para a referência e contra-referência também se mostrou precário, como admite o ex-secretário de Políticas de Saúde, ao ser entrevistado para o estudo da Rede Observatório de Recursos Humanos em Saúde: "(...) referências, esse é um problema, não se tinha... e isso era de se esperar porque eram os piores, entre aspas, entre os municípios, 
eram exatamente aqueles que explicavam a situação epidemiológica pior de todo o país (...)" (Maciel Filho, 2007: 192-193).

0 transporte para deslocamento dos profissionais nas áreas onde 0 Pits estava implantado era uma das contrapartidas dos municípios. No entanto, a partir de dados da avaliação promovida pelo M inistério da Saúde, o Relatório de Gestão de 2002, informa que:

Embora o transporte exista em quase $60 \%$ dos municípios, nem sempre o serviço está disponível. Entre os que responderam a essa questão, 39,4\% afirmaram que o transporte está sempre disponível, $48,9 \%$ responderam que a precariedade do transporte está dificultando bastante o desenvolvimento do trabalho, e 11,7\% afirmaram que o transporteestá sendo providenciado pelos gestores. (Brasil, 2002e: 61)

Isso talvez explique o dado, obtido na mesma avaliação, de que somente $52,8 \%$ dos médicos realizavam visitas domiciliares nas áreas atendidas pelo Pits.

Os municípios deviam prover moradia e alimentação para os profissionais, o que também, em geral, revelou problemas, conforme destaca o ex-secretário de Políticas de Saúde, em sua entrevista para o estudo da Rede Observatório:

Outro problema, que era uma certa dificuldade de alguns municípios de oferecer aquelas condições mínimas, por falta de vontade política, por dificuldade concreta de inexistir às vezes até imóvel; o melhor imóvel, às vezes, que existia era o do próprio prefeito, às vezes tinha até prefeito que botava o profissional pra dormir na casa dele (...). (Maciel Filho, 2007: 193)

A moradia e a alimentação podiam ser proporcionadas diretamente pela gestão municipal ou por meio de ajuda de custos. Nos dois casos, foram inúmeras as queixas dos profissionais acerca do não cumprimento dessa contrapartida, seja pelas condições da moradia, seja pelos atrasos e mesmo não pagamento da ajuda de custos. Há várias manifestações a esse respeito no fórum do Pits, exemplificadas a seguir:

Prefeituras e estados pararam de pagar incentivos e a contrapartida e como já fizeram com colegas, que saíram em junho, não vão pagar os atrasados. (...) Bem, peço a todos que têm dinheiro a haver que se manifestem para que possamos mostrar aos nossos superiores o que está 
acontecendo. Nós, de [nome do município], estamos com a verba de alimentação e aluguéis atrasados há 3 meses. Os proprietários já ficam fazendo pressão sobre os profissionais para receber (...). (Fórum Pits)

Aqui em [nome do município], a situação é a mesma. Estamos com 4 meses de atraso na ajuda de custo e acho meio difícil recebermos, uma vez que até hoje nenhum colega que deixou o programa recebeu. Estamos, como sempre, negociando com os gestores junto aos tutores pela quitação da dívida. Imagino que só se resolva judicialmente (...). (Fórum Pits)

Nós que éramos de[ nomedo município] eo município foi descredenciado, o que culminou com a nossa saída em junho, nunca recebemos os dois meses de atraso e atéagora só promessas. Pra ser bem realista, sabe quando vamos receber esse dinheiro? Nunca!!! Por isso (...) a hora é essa, quem está com a ajuda de custo atrasada realmente tem que se articular, e os colegas que não estão sofrendo com o atraso devem dar o apoio necessário para os demais com idéias e sugestões. Aqui em [nome do município], nossa ajuda de custo é de $\mathrm{R} \$ 300,00$, que são revertidos em alimentação, não nos é dado dinheiro e sim um 'vale' (...). Não é a melhor opção, mas com certeza todo mês esse valor é garantido. (Fórum Pits)

Nossos gestores continuam achando que estão nos fazendo um favor em nos 'aceitar' no município, que devemos mendigar a ajuda de custo que é direito nosso edever deles. Nós somos profissionais edevemos ser respeitados. (Fórum Pits)

Como médico, fui admitido no Pits, em agosto próximo passado, primeiramentena cidade de [nome do município], ficamos sabendo, extraoficialmente, que o município não dispunha de verba ( $R$ \$ 500,00/ mês) para manter mais um profissional de saúde. Acredite se quiser. Por fim, fomos lotados em [nome do município] (...). Após nossa lotação ficamos sabendo que parte dos recursos para nossa manutenção seria fornecida pelo poder executivo municipal, os tais 500 reais. Acreditamos que tudo caminhasse dentro dos conformes. Ingenuidade! Já se passaram 4 meses e recebemos apenas o valor referente ao 1 o mês. (Fórum Pits)

Vários profissionais recorreram à justiça, depois de tentarem resolver o problema junto à coordenação nacional e estadual sem sucesso, conforme depoimentos no fórum.

Quando a coordenação nacional comunicou que o Pits deixaria de existir como tal e suas equipes seriam incorporadas aos sistemas municipais de saúde, imediatamente os profissionais se manifestaram no fórum, demonstrando todo o descrédito acerca da seriedade e da capacidade de gestão dos municípios:

Se o Pits for vinculado ao município eeste receber a verba repassada pelo MS, será que eles irão nos pagar? Se nem a ajuda de custo que é um valor irrisório eles pagam, o que dirá o nosso salário!!! (Fórum Pits) 
No município de [nome do município], a conta da prefeitura está bloqueada pelo juiz para pagamento de pendências jurídicas. Como teremos garantia de receber em dia se não conseguimos sequer receber a ajuda de custo? (Fórum Pits)

A priori, os municípios selecionados para receberem o Pits tinham como características: indicadores desaúderuinse deficienteinfra-estrutura desaúde (até ausência de unidades hospitalares, se não me engano). Para esses municípios era muito difícil a contratação de médi cos e enfermeiros, devido às suas situações financeiras delicadas, localização geográfica (em alguns casos) e falta de infra-estrutura, de uma maneira geral. Portanto, o Pits surgiu como uma estratégia para viabilizar a fixação ('interiorização') de médicos e enfermeiros em municípios carentes. Entretanto, foi concebido também como um mecanismo temporário para a implantação, a posteriori, da estratégia de Saúde da Família (PSF). Como esses municípios podem manter os profissionais de saúde que lá estejam ou contratar novos profissionais? Quais são os atrativos pra isso? (Vale a pena lembrar que os profissionais perderão a 'pseudo-estabilidade', a certeza de receberem os seus salários em dia, a 'imunidade política', o acesso à internet, entreoutras coisas mais...). ( ...) Receio que o município corra o risco de nos perder e não ter condições de implantar o PSF, e queisso venha a acontecer também a outros municípios do Pits. (Fórum Pits)

A preocupação dos profissionais mostra-se ainda mais fundamentada quando se observa que al guns municípios não conseguiam sequer manter os agentes comunitários de saúde, embora recebendo recursos do Programa de Agentes Comunitários de Saúde (Pacs), conforme relatado por alguns profissionais no fórum.

Em outros casos, os profissionais do Pits verificavam, nos próprios municípios de atuação, precarização das relações de trabalho estabelecidas entre as respectivas prefeituras e outros profissionais contratados para o sistema municipal de saúde, inclusive com atrasos no pagamento dos salários. Há vários relatos no fórum:

Um dos problemas que [nome do município] está ainda tentando resolver éa regularidade e permanência dos vários profissionais de saúde, sob a sua administração. Muitíssimos profissionais (...) tiveram dificuldades em permanecer na cidade por vários motivos, inclusive, devido ao atraso de até dois a três meses no pagamento de salários. As equipes do Pits, que detêm cerca de $60 \%$ da área assistida deuma atenção primária que abrange $100 \%$ da população, puderam permanecer mais estáveis, também, graças ao fato de, recebendo nossos salários do governo federal, estarmos mais protegidos contra os atrasos de pagamento. Meu sonho é um dia trabalhar com uma população cada vez mais sadia e em um município queadministre plenamente a sua saúde. Porém, os problemas de ordem econômica e financeira ainda vigentes são fatos incontestáveis que evocam um 
planejamento a médio ou longo prazo. Gostaria muito de poder trabal har, recebendo salário diretamente da administração de [nome do município], porém isto seria um pouco difícil, em termos de regularidade no pagamento, o quecomprometeria, certamente, a nossa estabilidade. As várias propostas para o futuro do Pits deverão levar em conta que os municípios em que fomos lotados foram escol hidos devido aos seus vários marcadores eíndices de saúde, que chamaram a atenção da nossa nação. As transformações estão havendo, porém, dependemos de tempo e paciência, a fim de encontrarmos caminhos seguros para a construção de uma saúde sustentável. (Fórum Pits)

O ex-secretário de Políticas de Saúde, em entrevista para o estudo da Rede Observatório, admite que a preocupação demonstrada pelos profissionais quanto à sua inserção nos sistemas municipais tem fundamento:

A gente não tem ainda um modelo de vinculação que permita, obviamente que por si só não, mas que permita contribuir bastante para o processo de fixação. Então, certamente, o que pesa é a faixa de remuneração, o cumprimento daquele acordo de trabal ho, pagamento mais ou menos em dia e a oferta de condições de trabalho. São aspectos que efetivamente pesam na possibilidade do médico ver aquele município como um município propício pra ele desenvolver um trabalho e uma inserção e uma carreira. (Maciel Filho, 2007: 198)

O secretário de Gestão do Trabal ho e da Educação na Saúde, no período de 2005 a 2006, que em 2001 atuou como consultor no processo de formulação do Pits, também admite essa dificuldade, em sua entrevista para o mesmo estudo, e relata que o problema foi tema de debate quando da formulação do Programa:

As pessoas não vão por quê? Hoje está muito claro, não vão porque os filhos começam a estudar (...), não vão porque se sentem inseguras e não vão porque - outra razão que surgiu que é muito importante na nossa discussão - é porque, exatamente, o setor municipal, ainda que pague melhores salários, ele não tem uma garantia de continuidade muito grande como teria, por exemplo, um arranjo em nível federal. (Maciel Filho, 2007: 198)

0 mesmo entrevistado destaca que "a visão política estreita de grande parte desses gestores, que administram os municípios como 
extensão de suas casas" é outro aspecto que desgasta a relação dos profissionais com os gestores, em municípios pequenos e com precária estrutura de gestão:

Atende a alguém da oposição? Esse caso é relatado. Atende a alguém da oposição? 0 prefeito indica que não quer mais pagar no mês seguinte, ou porque a primeira-dama resolve... como 0 prefeito paga, ele faz o seguinte... esse cara é meu funcionário, e funcionário muitas vezes nesse caso é considerado funcionário da minha casa, meus interesses, ele tem que atender, tem que atender à consulta que eu estou mandando e não a uma ordem pública, por exemplo. Então, todas essas questões foram levantadas na época e se pensou que um instrumento de pagamento de uma bolsa federal poderia ser um instrumento de garantir, dar rumo e sustentabilidade ao projeto mais a médio e longo prazo, né. E de fato funcionou. (Maciel Filho: 2007: 198)

O Pits garantia, nesse sentido, o que um dos médicos, em mensagem citada alguns parágrafos anteriores, denominou 'imunidade política'. Segue o entrevistado:

Como é que eu garanto que a pessoa não tenha a labilidade do humor do prefeito? Às vezes, nem é humor também não, às vezes o município fica de fato sem caixa durante um período, porque o repasse dos fundos federais e estaduais não aparece e não tem caixa mesmo, paga outra coisa em vez de pagar a pessoa; enfim, esta estabilização, eu acho que é uma coisa muito importante pra se falar (...). (Maciel Filho, 2007: 198)

A esse respeito, outro entrevistado, o ex-secretário de Políticas de Saúde, chama a atenção para o fato de que, por vezes, a própria conduta dos profissionais não facilitava a relação com o gestor municipal:

Em alguns municípios tem as características do próprio profissional, um profissional talvez um pouco mais, vamos dizer assim, mais crítico; então havia, houve, em alguns municípios, queixas dos gestores quanto ao comportamento dos profissionais, fazendo referência a essa pretensa autonomia deles (...). ( Maciel Filho, 2007: 199) 
Outro entrevistado que também aborda o problema é o representante do Conasems, acrescentando que, se por um lado, o Pits garantia essa 'imunidade'; por outro, esse mesmo fator funcionava, em alguns casos, como um elemento de distanciamento entre os profissionais e 0 gestor e as estruturas municipais:

Porque depois ele começa a ter conflito entre o médico e 0 secretário de saúde, e o médico passa a dizer que não tem nada a ver com o secretário. Você tem conflito entre o médico, o secretário e as universidades que vão titular os profissionais. Em alguns municípios, o Pits termina sendo uma coisa paralela à Secretaria Municipal de Saúde. Então essa coisa mostra que, na estrutura do sistema atual de saúde brasileiro, esse tipo de política tem vida curta. Ela nasce como Programa e termina acabando mesmo, por isso que, inclusive, o Conasems já na 12 a Conferência Nacional de Saúde aparece para defender a substituição do Pits por uma política permanente, global, na solução desse problema.(...) . ( Maciel Filho, 2007: 199)

\section{Síntese da Experiência}

Tal como entendido pelo Ministério da Saúde, o Pits

pode ser configurado como uma política de indução ou de redirecionamento na distribuição dos recursos humanos para o SUS, que busca interiorizar a atuação de médicos e enfermeiros, por intermédio da captação voluntária e estimulada destes profissionais mediante incentivos e benefícios claramente definidos. (Brasil, 2002e: 65)

A análise do Programa como estratégia de intervenção para enfrentar o problema da má distribuição de médicos no país permite que se identifiquem diversos fatores que devem ser considerados em futuras iniciativas que tenham o mesmo propósito.

Os benefícios e incentivos oferecidos aos profissionais funcionaram, efetivamente, como um fator de atração, gerando o interesse de milhares de médicos que se inscreveram no Programa. 0 curso de especialização, a remuneração, o fato de se tratar de um Programa do Ministério da Saúde e de funcionar nos mesmos moldes do PSF, além da possibilidade 
de conhecer outras áreas do país foram os fatores considerados mais atrativos.

No entanto, aqueles que desistiram antes de atuar no Pits haviam sido movidos pelo interesse na remuneração como fator mais atrativo. Isso revela que se o interesse do profissional se dá eminentemente por aspectos financeiros, sua mobilização para participar de uma iniciativa desse tipo é vulnerável a inúmeras variáveis (pessoais, familiares, profissionais etc).

Ao contrário, aqueles que chegam a atuar numa iniciativa como essa, mesmo que desistam depois, identificam o curso de especialização como o fator mais determinante no seu interesse em participar. Não por acaso, a maioria dos médicos que chegaram a atuar não havia feito nenhum curso de pós-graduação. E foram exatamente profissionais sem pós-graduação que, de modo geral, renovaram sua participação por mais um ano. Esses dados mostram que a dificuldade de completar sua formação médica, em nível de pós-graduação, e a possibilidade de abrir uma nova perspectiva de inserção no mercado de trabalho funcionam como elementos mobilizadores para que esses profissionais se disponham a participar de iniciativas de interiorização.

0 fato de o perfil de formação dos médicos que efetivamente participaram do Programa estar concentrado na faixa de mais de 15 anos de formados, de modo compatível com o que se verifica no PSF, mostra que o modelo de atenção do PSF é particularmente atrativo para profissionais que já ultrapassaram a 'fase de afirmação profissional' e se encontram na 'fase de consolidação profissional', como denomina Machado (1997). Possivelmente, o estresse urbano vivido por esses médicos nas grandes e médias cidades contribui para a disposição em atuar em municípios de menor porte.

De forma conseqüente com esse perfil, a maior parte dos médicos que efetivamente participaram do Pits tinha mais de 40 anos de idade, eram casados, do sexo masculino, com dependentes, provenientes da Região Nordeste e graduados também no Nordeste.

Embora os médicos da Região Sudeste tenham demonstrado interesse em participar do Programa, tendo sido a região com o maior número de inscritos, foram também eles que demonstraram maior dificuldade em atuar nos municípios. Assim, a maioria dos médicos que concluíram um ano no Pits ou renovaram sua participação por um ano ou mais era proveniente das regiões Nordeste e Norte. 
Além da maior facilidade de adaptação dos médicos originários das regiões Nordeste e Norte, esses profissionais mostraram-se particularmente sensibilizados com as condições de vida e saúde da população de seus estados e regiões.

O Nordeste também se destacou como região de graduação da maioria dos médicos que concluíram um ano ou renovaram sua participação no Programa. A Região Norte, surpreendentemente, formou quase $20 \%$ dos médicos que concluíram um ano no Pits, sendo também a região de origem de $20 \%$ dos médicos lotados. Isso faz supor que os médicos oriundos da Região Norte se graduaram nessa mesma região e aponta uma tendência de interesse de fixação desses profissionais na própria região onde habitam e se formaram.

Ao longo dos três anos de vigência do Pits, somente $46,3 \%$ dos médicos que chegaram a ir para os municípios concluíram um ano de participação no Programa. A Região Norte foi a que apresentou a mais baixa capacidade de fixação de profissionais.

As constantes desistências e desligamentos se deram por motivos variados, mas em geral são atribuídas, pelos profissionais, à própria dificuldade de adaptação às condições adversas dos municípios, aos conflitos na relação com os gestores municipais e à desorganização na condução do Programa. Os médicos desistentes ou desligados são, em sua maioria, do sexo feminino, solteiros ou descasados, com dependentes, provenientes e formados na Região Nordeste. Mas o Sudeste apresenta um índice como região de graduação dos desistentes ou desligados bastante superior à sua participação como região de graduação dos que concluíram um ano ou renovaram. A maioria dos desistentes/desligados era proveniente dos estados do Rio de J aneiro e São Paulo.

Poucos profissionais optaram por renovar sua participação, mesmo com o incentivo financeiro criado pelo Ministério da Saúde para este fim, o que mais uma vez confirma que não é o atrativo financeiro que tem maior peso na decisão dos médicos em relação à interiorização.

A maioria dos médicos que chegou a participar do Pits não levou familiares, cônjuge ou companheiro(a) para os municípios. Mas no caso dos que levaram, os acompanhantes permaneceram, em geral, até o término da participação do profissional no Programa. Os dados obtidos pelo estudo da Rede Observatório mostram que o fato de levar familiares ou parceiros não funcionou como fator determinante na permanência dos médicos nos municípios. 
No entanto, a distância da família e dos amigos foi tema de várias mensagens entre os profissionais no fórum do Pits, onde argumentam que o fato de o Programa ser destinado a populações carentes e sem assistência acabou funcionando como uma certa compensação emocional pela ausência de seus entes queridos.

Os médicos consideraram, em sua maioria, 'a atuação profissional junto às comunidades carentes' como o fator mais satisfatório da participação no Pits, seguido do curso de especialização.

A boa avaliação que os médicos, de modo geral, fizeram da experiência de ter participado do Pits, apesar dos problemas enfrentados, é reforçada pelo fato de mais da metade deles defenderem, como rumo ideal para o Programa, sua manutenção no formato que possuía, mas com aperfeiçoamentos constantes.

A condução do Programa pela coordenação nacional foi cheia de percalços e enfrentou considerável desgaste na relação com os profissionais. Houve problemas relevantes em componentes fundamentais da estrutura do Pits, sob responsabilidade da coordenação nacional, como a tutoria, a supervisão, o curso de especialização, as atividades de educação continuada, a conectividade e a farmácia básica.

Embora a coordenação nacional tenha procurado superar essas dificuldades e minimizar os transtornos para os profissionais, é inegável a insatisfação gerada, que se agravou a partir de falhas importantes no processo de comunicação entre os participantes e os gestores do Programa. Se os problemas no cumprimento de garantias previstas no regulamento do Programa, por si só, já prejudicavam o exercício das atividades dos profissionais e tornavam suas condições de trabalho ainda mais precárias, as falhas de comunicação potencializaram o desgaste, a impaciência e a insatisfação, gerando questionamentos quanto à capacidade de organização e de gestão da coordenação nacional.

Quando começaram a surgir os comentários acerca da extinção do Programa e da incorporação dos profissionais aos sistemas municipais de saúde, mediante repasse direto de recursos financeiros, agravaram-se os problemas, as dificuldades e os ruídos de comunicação.

A atuação do TCU e do Ministério Público do Trabalho evidenciou que a alternativa adotada de remunerar os profissionais por meio de uma bolsa do CNPq não foi uma solução adequada do ponto de vista da sustentabilidade do Programa. Mesmo considerando que, já na formulação do Pits, previa-se sua posterior incorporação aos sistemas 
municipais, essa estratégia poderia levar - e realmente levou - a que o Pits se tornasse uma estrutura paralela a das secretarias de saúde locais. Além disso, foi uma estratégia que, ao fim e ao cabo, camuflou uma relação precária de trabalho, condição tão debatida e desestimulada pelo próprio Ministério na última década.

Possivelmente, se o Programa tivesse sido formulado num contexto em que não envolvesse interesses relacionados à sucessão presidencial, ${ }^{13}$ o modelo adotado para seu funcionamento poderia ter sido mais debatido e negociado, talvez para algo mais próximo de um serviço civil voluntário, o que certamente demandaria um tempo mais longo do que o tempo político que gerou o Pits.

Essa hipótese pode explicar porque, embora sua formulação tenha envolvido parceiros estratégicos, isso foi insuficiente para que o Conass e o Conasems tenham atribuído à sua participação um caráter efetivamente de co-partícipes e responsáveis pela definição dos mecanismos, estratégias, gestão e rumos do Pits. Por conseqüência, as coordenações estaduais e os municípios tiveram um envolvimento muito mais administrativo e operacional do que propriamente político e de efetivo comprometimento com a Programa. Com isso, a coordenação nacional acabou figurando, na prática, como gestora única do Programa, assumindo, conseqüentemente, os ônus e bônus dessa posição. Nem mesmo a relação direta estabelecida com os municípios desde os primórdios do Programa rompeu esse isolamento, uma vez que não se tratou de uma relação de co-gestão, mas sim de caráter operativo.

É possível afirmar que o Pits não se sustentou como uma estratégia de interiorização muito mais em decorrência da verticalidade de sua gestão e da inserção politicamente restrita atribuída aos estados e municípios do que em função das dificuldades de outras ordens. M esmo porque, boa parte dessas dificuldades ocorreu exatamente por esse motivo.

O próximo capítulo propõe-se a explorar esse e outros elementos fundamentais para o exercício de pensar estratégias e alternativas que permitam enfrentar o desafio que a má distribuição ea fixação de médicos nas regiões mais desfavorecidas representam, hoje, para o SUS.

13 O ministro da Saúde na época - J osé Serra - era potencial candidato à Presidência da República nas eleições que se realizariam em 2002. 